\title{
Port Development and the Environment: External Costs from Dredge Disposal and Air Pollution ${ }^{1}$
}

\author{
Thomas Grigalunas", Simona Trandafir", and Meifeng Luo"**, \\ James Opaluch" and Suk-Jae Kwon*.**
}

\begin{abstract}
This paper analyzes two external costs often associated with port development, cost to fisheries from marine dredge disposal and damages from air pollution, using estimates of development and operation for a proposed (but since cancelled) container port as a case study. For dredge disposal, a bio-economic model was used to assess short-and long-term and indirect (foodweb) damages to fisheries from marine disposal of clean sediments. In the case of air pollution, estimates of annual activity levels and emission coefficients are used to estimate incremental annual emissions of three key pollutants (NOx, HC and CO) for trucks, trains, yard vehicles, and vessels. These estimates allow for phasing in of strict new air pollution regulations. For both external costs, sensitivity analyses are used to reflect uncertainty. Estimates of shadow values in year 2002 dollars amount from $\$ 0.094$ per cubic yard to $\$ 0.169$ per cubic yard of clean dredged material for the selected disposal site and from $\$ 0.0584$ per mile (for current control standards) to \$ 0.0023 per mile (after phasing in of new regulations) for air pollution from heavy trucks.
\end{abstract}

Keywords: Environment, Environment and Ports, Economic Damages and Ports, Air Pollution and Dredge Disposal Costs, Intermodal Environmental Costs

\section{INTRODUCTION AND BACKGROUND}

\section{Introduction}

Efficient port and related intermodal systems are critical for international trade and economic growth, yet planning for these systems often raises difficult environmental issues. Port development typically requires filling in of coastal lands; dredging of

\footnotetext{
'Professor, " Ph.D. Student, "'Research Associate, Department of Environmental and Natural Resource Economics, University of Rhode Island, Kingston, RI USA 02881, '”Korea Ocean Research and Development Institute

Corresponding author: Thomas Grigalunas (e-mail: grig@uri.edu)

' The authors gratefully acknowledge financial support from the University of Rhode Island Transportation Center, the Korea-America Joint Marine Policy Research Center at URI, and earlier support from the US Army Corps of Engineers.
} 
berths, channels, and turnaround basins, and a subsequent need to dispose the dredged material. Once on line, port-related vessel, vehicular, and train traffic can cause air pollution, traffic congestion, accelerated roadway wear and tear, and exposure to unwanted lighting and noise, particularly for surrounding residential areas and homes near heavily traveled routes.

The above (and other) port-related environmental issues — both real and perceived - are a concern for port planners and the public throughout much of the world. For example, in many Asian countries environmental issues such as land reclamation, air quality, congestion, and non-native species are receiving increasing attention (PEMSEA, 2003), and a recent summary of environmental issues affecting selected major United States container port proposals found that environmental issues played a major role in port development decisions (Grigalunas, et al., 2003). In virtually every significant US port proposal studied, environmental issues caused notable redesign, delays, and higher costs. Outright cancellation due largely to environmental issues also occurred.

In short, environmental concerns - external costs and public bads - often affect the economic (and perhaps political) feasibility of proposed facilities, and hence are an important factor in port and related intermodal planning (Transp. Res. Board, 2002). In this context, estimates of potential external costs or shadow prices can contribute to port and related decisions in several ways. First, monetary estimates of benefits and costs provide information about public preferences in a common metric dollars and, by that put potential external costs in perspective. Monetized estimates of environmental costs also expand the costs and benefits which can be included in port-related analyses and provides information on the distribution of potential environmental costs. If policy decisions are to reflect all benefits and costs, then estimates should include not only discounted market economic benefits, $B$, (e.g., transportation cost savings) and costs (the opportunity costs of the resources used), $C$, but also non-market environmental costs, $E_{C}$, and possible environmental benefits $E_{B}$, plus the costs of mitigation, $M^{2}$ :

Net Discounted Benefits $=\left[(B-C)-\left(E_{C}-E_{B}\right)-M\right]>0$ ?

Lacking information, potential environmental costs may be grossly misperceived by the public or decision makers with no appreciation of their relative significance. Beyond that, estimates of potential external costs can contribute to decisions concerning (1) the timing of dredging (use of environmental "windows" - periods when dredging would cause minimal harm), (2) site selection for marine dredge disposal, and (3) avoidance and mitigation of noise, wetlands losses, and other issues. Additionally, estimates of external costs can aid in using virtual ("equilibrium") prices in transportation policy, so that transportation costs include full social costs - private as well as environmental costs (e.g., Ozbay, Bartin and Barechman, 2001).

\footnotetext{
${ }^{2}$ For consistency, when mitigation costs $M$ are included, environmental costs and benefits, $E_{c}$ and $E_{p}$, should be measured net of the effects of mitigation actions.
} 
At the same time, it must be acknowledged that many port-related externalities are difficult to assess. For one thing, cause-and-effect links must be established for each source of environmental stress, extending from the development (e.g., dredging or filling in of sub-tidal lands or intertidal wetlands) and operations (e.g., trucking) activities to the ultimate costs imposed on the public. Further, assessing external costs requires the use of non-market concepts and methods, which in turn may necessitate drawing upon biological, engineering, and other information comprising the important "non-economic foundation" needed for valuation of natural resource and environmental services (e.g., Freeman, 2003). Additional challenges arise because policy analyses are concerned with incremental effects, and identifying realistic with-versus-without port effects is not always obvious. Finally, estimates of potential external costs should acknowledge proposed environmental regulations and mitigation measures which might reduce the environmental costs of development. For all of these reasons, integrating environmental issues in port-related planning raises daunting challenges for research and policy.

\section{Purpose and Scope}

This paper summarizes selected research by the authors and their colleagues on environmental issues in container port and related intermodal planning. Using a proposed (and now cancelled, largely because of environmental concerns) container hub port as a case study, we summarize concepts, methods, and data used to assess environmental costs associated with two issues: (1) marine dredge disposal and (2) air pollution. These examples capture commonly raised, and typically controversial, public concerns and pose interesting methodological issues. Other port-related environmental issues are addressed in recent reports and papers as part of an ongoing program at the University of Rhode Island which seeks to integrate key financial, economic, and environmental analyses in port planning ${ }^{3}$.

\section{Organization}

Section II describes generic port-related environmental issues and also presents core economic concepts. In Section III, estimates are given of selected annual development and operating activities at the proposed port. These estimates (e.g., for the intermodal split and annual truck trips) provide the underpinning for the assessment of environmental issues. Then, in Section IV, the two case studies of environmental issues are summarized. To economize on space, an abbreviated presentation of methods, data, and key results are presented, with readers referred to specific publications for more detail. The final section contains a summary, conclusion, and necessary qualifications. An appendix provides a brief discussion of the spatial-economic simulation model relied upon in the paper.

\footnotetext{
${ }^{3}$ Details on research by the authors and their colleagues to sort out, financial, economic, and environmental costs and benefits to major stakeholder entities in port planning are given in Grigalunas, Luo and Chang (2001); Grigalunas, Opaluch, Chang, and Luo, 2001; and Grigalunas, et al., 2004).
} 


\section{POTENTIAL PORT-RELATED ENVIRONMENTAL ISSUES, CORE CONCEPTS AND METHODS}

\section{Potential External Costs}

\section{Generic Environmental Issues}

While specific issues vary between ports, potential externalities because of container ports include ${ }^{4}$ :

- the effects of dredging and dredge disposal on fisheries and ecosystems;

- air emissions from on- and off-dock container-related vehicles, rail traffic, and vessels;

- loss of wetlands, shoreline, and bay bottom due to filling to create port lands;

- offsite, peak-use road congestion;

- traffic delays at offsite rail crossings because of container train traffic;

- accelerated wear and tear on roads from heavy duty trucks;

- loss of open space amenities in nearby communities;

- light and noise externalities near ports and, for noise, along routes heavily traveled by trucks;

- water pollution from storm water runoff,

- physical interference with seasonal fish spawning runs,

- introduction of non-native species in ballast water,

- conflicts with commercial fishing and recreational uses of area waters, and

- public access to coastal areas.

\section{Cause-and-Effect Links}

Listing potential environmental issues is easy, but assessing their significance can be very hard. To quantify external costs sequential, cause-and-effect links must be established for each potential environmental cost. These links involve quantifying:

1. port-related activities causing the environmental stresses (e.g., sediment dredging and disposal; truck traffic)

2. the resultant environmental stresses (e.g., air pollution, dredge disposal, loss of open space amenities, congestion, noise);

3. exposure of resources or people to the stress (e.g., exposure to air emissions and noise);

4. injury or harm to resources or people exposed;

5. loss in the quantity or quality of services (e.g. fish harvests);

6. change in behavior (e.g., avoidance or moving to substitute site); and finally

7. the loss in economic value experienced by the public (e.g., lost value of fish

${ }^{4}$ Oil spill environmental risks are not listed because they likely are of much less concern at container ports of interest in this paper than at ports where large volumes of oil are transferred. 
harvests; air pollution damages to health or materials; adverse effects from noise).

As a first step, incremental port-related activity levels (link 1) must be estimated. This requires a projection of activities (e.g., road traffic in the case of air emissions) in the with-port case over and above those arising from an alternative use of the available land (the without-port case). Links 2-4 involve the natural sciences, underscoring the need for multidisciplinary information. The extra-market nature of externalities requires the use of non-market valuation methods to address items (5) (7) above (e.g., Freeman, 2003). Additional and related problems involve assessing the net benefits of proposed policies, such as use of dredging windows (Grigalunas, Luo, and Opaluch, 2001) $)^{5}$ and other mitigation measures, or undertaking costeffective compensatory restoration in order to avoid or offset anticipated external costs (Mazzotta et al, 1994).

\section{Core Concepts}

At a conceptual level, we want to estimate the economic value of the incremental environmental stresses resulting from port development. In terms of welfare economics, suppose that planned port development causes air, noise and other externalities, by that lowering the environmental quality individuals would experience from an initial level " $Q_{0}$ " to a lower level, " $Q_{1}$ ", where $Q$ is a vector of environmental services. The measure of external cost is the most that someone would pay to avoid environmental outcome $Q_{l}$ and keep the current level of environment services, $Q_{0}$. This can be stated simply as:

$$
V\left(\text { Income-WTP, } Q_{0}\right)=V\left(\text { Income }, Q_{l}\right)
$$

where $V(\bullet)$ is the indirect utility function, and WTP is the most an individual is willing to pay, such as for a house in a cleaner or quieter neighborhood, in order to avoid the decrease in environmental quality from the level $Q_{0}$ to $Q_{l}$. Hence, WTP in this case is a measure of equivalent surplus.

However, if individuals have the right to the pre-development quality, $Q_{0}$, then we should estimate the compensation required for residents to accept the additional noise, dirtier air, or other environmental harm. The required willingness to accept compensation (WTAC) in lower taxes or improved public services, for example, for an individual to accept the deterioration from $Q_{0}$ to $Q_{1}$ is:

$$
V\left(\text { Income, } Q_{0}\right)=V\left(\text { Income }+ \text { WTAC, } Q_{l}\right)
$$

In this case, individuals are no worse off with, than they were without, the development because they have been compensated for the degradation from $Q_{0}$ to $Q_{1}$. Hence, WTAC is an estimate of compensating surplus. WTAC is more difficult to

\footnotetext{
${ }^{5}$ Use of dredging windows is intended to schedule site dredging activities to avoid harm to fisheries or other resources during critical spawning/migration periods. An analysis of the some of the difficulties in setting windows involved is given in Grigalunas, Luo and Opaluch (2001)
} 
measure than WTP (Knetch and Sinden, 1984; Freeman, 2003; Hanley, Shogren and White, 1997) ${ }^{6}$. As a result, WTP rather than WTAC is usually employed and provides a conservative (lower bound) estimate of WTAC (Carson, Flores, and Hanneman, 1998) ${ }^{7}$. Estimates of WTP (or WTAC) must be aggregated over the affected populations to get total environmental costs, and the impacted population may differ from issue to issue. Given that distributional effects often are central to adoption of environmental decisions (e.g., Zeckhauser, 1985), it can be very important to understand the distribution of costs, for example, costs borne by commercial and recreational fishing interests, or imposed on the public at large from incremental air pollution and noise.

\section{Choice of Methods for Modeling External Costs}

In this paper, port-related external costs are estimated for individual externalities. This issue-specific, additive approach is useful because policy debate often concerns particular issues, and there are many of them, as noted in the introduction. Of course, care is needed to avoid double counting where two methods might capture some of the same economic values ${ }^{8}$.

An alternative would be to use the contingent valuation method (CVM) and consider all externalities together in an attempt to estimate total value (e.g., Mitchell and Carson, 1989; Randall, 1991; Freeman, 2003). This approach avoids possible double counting. It also avoids the problem that summing individual, independently estimated values may (because of substitution and income effects) yield different results than a valuation of the same resource changes estimated in a single study of total value. However, well done (valid and reliable) CVM studies are very expensive. Further, CVM almost certainly would require a level of abstraction for developmentenvironmental issues which would not help resolve disputes over the numerous, individual resource- and area-specific environmental concerns which are common in port development debates. Finally, CVM studies of passive use values remain problematic (e.g., Hausman, 1993), despite important advances in the state-of-the-art.

Another stated preference method, Contingent Choice (CC), might be better suited than CVM for assessing multiple port-related externalities. CC involves using carefully developed surveys to elicit respondents' willingness to tradeoff resources or amenities in well-specified alternative resource programs (Mitchell and Carson, 1989; Opaluch, et al, 1999; Mansfied, Van Houten, Huber, 2002). Again, such surveys are

${ }^{\circ}$ Differences between WTAC and WTP depend upon the availability of substitutes for affected resources and the income effect (Hanemann, 1991; Hanley, Shogren, and White, 1997).

${ }^{7}$ Who has the property right for environmental resources (such as when authorized dredging harms recreational uses) is not always obvious and can vary from issue to issue in port planning. Hence, the conceptually correct use of WTP or WTAC may not always be clear.

${ }^{8}$ For example, a hedonic method might estimate the marginal (use) value of open space to adjoining residents, but a contingent choice assessment might measure total value of the open space to the public at large (for an example see, Johnston et al., 2001). Since adjoining residents are also member of the public at large, the value of open space calculated using two different methods might double count open space benefits. 
expensive to do well, and the large number of complex port-development issues involved likely would overwhelm the cognitive ability of the general public to respond meaningfully to survey questions with many choice alternatives ${ }^{9}$. Other problems, such as responses which are symbolic of broad environmental concerns, rather than the specific issues at hand, also may arise (Opaluch, Mazzotta and Grigalunas, 2000).

\section{SIMULATION OF PORT DEVELOPMENT AND INTERMODAL TRANSPORTATION ACTIVITY LEVELS}

Port-related scale, temporal, and spatial issues are critical for assessing environmental effects. In keeping with our interest in developing integrated, theorybased methods for linking port development, demand for port and intermodal services, and the environment, a simulation approach is used, as we describe below.

Scale concerns the level of port activities - vessel, on dock, road, and rail usage per year - which are the source of potential externalities. Temporal issues refer to the timing of the port development and operations which generate potential external costs. Spatial issues concern geographical factors critical for understanding transportation modes, routes, and costs, to market areas served by the port. This information also underlies the geographic distribution of environmental stresses and hence external costs, for example, miles traveled on least-cost routes, discharges of key air emissions per mile, and exposure of area populations to environmental stresses.

The scale and timing of activity for a case study hypothetical port at Quonset Point on Narragansett Bay, RI used herein rests on estimates derived from (1) a primarily engineering study of development of the proposed port by RKJohns\&Assoc. (RKJA), and (2) an economic-spatial model which simulates container port and related intermodal demand for the planned first year of operation, the base year, 2008 (Luo, 2002 and Grigalunas and Luo, 2003). Also used are (3) projections of annual activity through the port for a 20-year planning operating period, using an average growth rate $(5.4 \%)$. This is the mean rate from an econometric estimation of demand for container services in twenty foot equivalent units (TEU) and a survey of demand projections in the literature (Jung, 2001; Grigalunas, Luo and Jung, 2002).

The timing of port development uses engineering design and planning concepts given in RKJA (Figure 1). Key assumptions include a six-year development period for dredging and disposal, site development, and terminal development, followed by a 20-year operating period, 2008 - 2027 for illustrative purposes.

\footnotetext{
${ }^{9}$ For a discussion of cognitive issues in surveys, see Mazzotta and Opaluch (1995)
} 
Figure 1. Timeline of Major Activities at Proposed Quonset Point Container Port

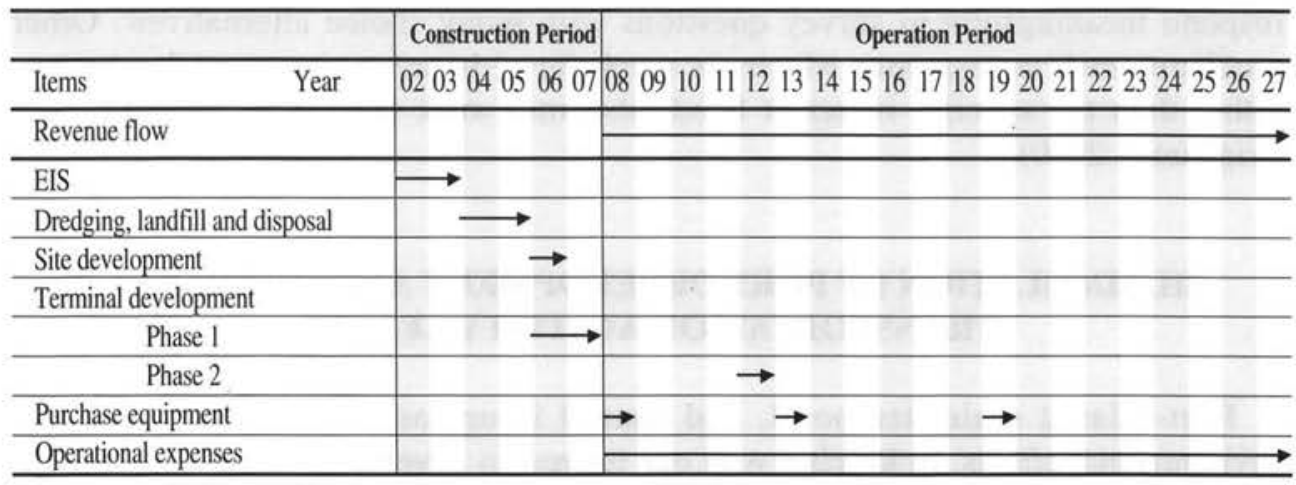

The demand for port services in TEUs and associated activity levels for vessels, road, and rail traffic, and other operations are given in Table 1 for benchmark years. Key estimates come from the results of the economic-spatial simulation model, noted above. The model estimates initial movements through the port of 211 thousand TEU increasing to 572 thousand by year 20. Seventy percent of containerized cargoes through the hypothetical port would move by train, largely to midwest US markets. The remaining $30 \%$ of TEU moves by truck serve the more local Northeast markets (Luo 2002, Luo and Grigalunas, 2002). The annual number of truck trips increases from 107 thousand in operating year one to 292 thousand 20 years thereafter. Heavy duty trucks are the major emitters of air pollution, and the number of truck trips becomes important in the later estimates of air emissions and externalities from this source.

In the spatial-economic model, spatial issues are examined within a GIS framework, which selects the least-cost transportation modes (port, truck and train) and routing for containerized cargoes moving in international trade (Luo, 2002; Luo and Grigalunas, 2003). Here we provide an overview of the simulation model used to estimate demand for port services for year one of operation.

Briefly, the estimated intermodal split and routes for containerized cargoes moving in international trade are based on minimizing transportation facility costs (port, road and rail) plus interest on the value of containerized cargoes. The unit of analysis for the case study port state (Rhode Island) and for the remainder of the Northeast US (New England plus New York) is at the county level. For the remainder of the mainland United States, the unit of analysis is at the state level.

All major US container ports are included - sixteen in all — with Los Angeles/Long Beach and Seattle/Tacoma, respectively, treated as single ports because of their proximity. The Canadian eastern ports of Montreal and Halifax also are included in the model because they compete with US ports for Atlantic cargoes of interest in our research. Foreign markets are divided into continents with Asia divided into East Asia and West Asia which starts at and includes Singapore. These continents are assumed to be served by the largest port. In sum, the model is a leastcost transportation model, not a trade model. Trade is taken as given in the model. 
Table 1. Base- Case Assumptions and Estimated Annual Activity Levels, Selected Years, for Hypothetical Hub Container Port at Quonset Point, RI

\begin{tabular}{|c|c|c|c|c|c|}
\hline \multirow{2}{*}{ 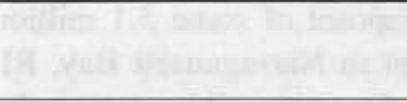 } & \multicolumn{3}{|c|}{$\begin{array}{ll}* * * & \text { Year }\end{array}$} & $* * *$ & \multirow{2}{*}{20} \\
\hline & 1 & 5 & 10 & 15 & \\
\hline TEUs $(000)^{\mathrm{ab}}$ & 316 & 390 & 507 & 659 & 858 \\
\hline TEU/Move $e^{e}$ & 1.5 & 1.5 & 1.5 & 1.5 & 1.5 \\
\hline Moves $(000)$ & 211 & 260 & 338 & 440 & 572 \\
\hline Annual Growth Rate ${ }^{d}$ & $5.4 \%$ & $5.4 \%$ & $5.4 \%$ & $5.4 \%$ & $5.4 \%$ \\
\hline \multicolumn{6}{|l|}{ Modal Split } \\
\hline Percent Rail & 70 & 70 & 70 & 70 & 70 \\
\hline Percent Truck & 30 & 30 & 30 & 30 & 30 \\
\hline Truck Trips/Move & 1.7 & 1.7 & 1.7 & 1.7 & 1.7 \\
\hline Truck Trips $(000)$ & 107 & 132 & 172 & 224 & 292 \\
\hline Truck Idle Time @ Port & $0.5 \mathrm{hr}$ & $0.5 \mathrm{hr}$ & $0.5 \mathrm{hr}$ & $0.5 \mathrm{hr}$ & $0.5 \mathrm{hr}$ \\
\hline TEUs/Train & 400 & 400 & 400 & 400 & 400 \\
\hline Train Trips & 368 & 455 & 591 & 769 & 1000 \\
\hline \multicolumn{6}{|l|}{ Vessels } \\
\hline Container Ships Visits & 105 & 130 & 169 & 220 & 286 \\
\hline Tugs (2/Ship) Visit & 210 & 260 & 338 & 439 & 572 \\
\hline
\end{tabular}

${ }^{2}$ Luo (2002)

${ }^{b}$ Grigalunas and Luo (2002)

${ }^{\mathrm{C}}$ Ratio assumed to be the same as at the Port of New York and New Jersey (PNYNJ)

J Jung (2001) and container forecast literature summarized in Grigalunas, Luo, and Jung (2001)

'Ratio assumed to be same as at the PNYNJ

\section{QUANTIFYING EXTERNAL COSTS: DREDGE DISPOSAL AND INCREMENTAL AIR POLLUTION}

This section describes the methods, key data, and results for the two external costs considered in this paper: (1) external costs to fisheries from dredge disposal during development, and (2) air emissions from port-related operations. Both cases use assumptions which tend to overstate costs. Sensitivity analyses are employed to reflect uncertainties and to examine how alternative assumption might affect the basecase results. Qualifications are provided later in the paper.

\section{Economic Cost to Fisheries from Dredge Disposal}

\section{Introduction}

Fishing industry and public concerns with the potential adverse effects of marine dredge disposal on fishery resources are a common and often very controversial element in port development. This case study considers the cost to fisheries of marine disposal of clean sediment at the site selected for material dredged in connection with the proposed port. First, we present the case study in which costs to fisheries were 
estimated for several candidate disposal sites. Then, we apply the results of the case study to estimate the costs to fisheries from marine disposal of material from the case study port at the planned marine disposal site.

This case study concerns the dredging and marine disposal of some 5.1 million cubic yards (3.9 million cubic meters) of clean sediment in Narragansett Bay, RI. Seven potential marine disposal sites were considered by the responsible agency, the US Army Corps of Engineers (USACE), three within Narragansett Bay and four outside the Bay, in Rhode Island Sound. Each of the sites differs with respect to its location, bathymetry, water depth, and with regard to the abundance of fish, mollusk, and crustaceans (primarily lobster). The mound created by sediment disposal preliminarily has been estimated to cover from 121 to 215 hectares, depending upon the site (L. Oliver, USACE, personal communication, August 15, 2000).

Disposal at a site may cause mortality to legal size and juvenile fish and may also have adverse ecosystem effects. Losses could be borne by recreational users and commercial fishers. In short, losses could be short-term or long-term, offsite as well as on site, and may involve non-market, recreational losses, in addition to marketvalued commercial losses. In short, considerable differences in site characteristics, resources, and uses exist between sites.

A cohort-type or age-class model (Ricker, 1975) was used since the model can capture the three elements of lost catch mentioned. Including cohorts can be very important, for example, if an area primarily serves as a nursery. In such a case, shortterm fishing losses may be negligible, but the long-term lost catch might be significant. Without a cohort-type model, long-term effects may be missed, or may have to be addressed in an ad hoc manner.

\section{Concepts and Data}

Our goal is to estimate the present value of lost economic rent for commercial fisheries and lost consumer surplus for recreational angling. These losses are assessed through the time to recovery of the affected species. The discounted value is the potential loss in the asset value of each site due to the lost productivity at the disposal site (Kopp et al, 1993; Freeman, 2003). The costs of transporting sediments to each of the sites could be important in the selection of the dredge disposal site but are not considered because such costs are beyond the scope of the environmental research reported on herein.

Three components of fishery losses due to sediment disposal are estimated: (1) short-term effects, (2) long-term effects, and (3) indirect (ecological-food web) effects. Standard methods are used for estimating each of these components of losses (EAI and ASA, 1987; Grigalunas et al, 1988). Specifically:

Short-term effects are economic losses due to reductions in catch during the disposal period as a result of mortality to adult fin fish, mollusks, and crustaceans. Following our overstated cost approach, disposal of the sediments involved is assumed to cause 100 percent mortality to all biomass in the disposal area over the entire 18-month disposal period. Short-term lost or foregone catch for a species thus is equal to the fishing mortality rate $(\mathrm{F})$ times the adult biomass $(\mathrm{B})$ for each species 
for the affected area over the disposal period.

Long-term effects are economic costs due to foregone catch over the period of recovery of the population, including losses due to mortality to adult fish, juveniles, and young-of-year. Long-term losses are determined by simulating recovery of the population following the disposal period using a Beverton-Holt, age-class model (Ricker, 1975). The model simulates the mortality and growth of each age class of the population for each species, and calculates the lost catch during the recovery period.

Indirect (food web) effects are the economic losses from reduced commercial and recreational catch due to impacts on food resources. Losses of food resources are translated to lost biomass of commercial and recreational species, and then reductions in catch. Following (ASA et al, 1996), we use a proportionality rule, whereby the fraction of predator species lost equals the fraction of prey lost due to disposal. Following our use of an overstated cost approach, we assume that all prey at a site is lost due to disposal of sediments at the site.

For short- and long-term effects, a Beverton-Holt approach (Ricker, 1975) was used to model the number and the weight of individuals for each age class. Before the age of recruitment to the fishery, the number of individuals in an age class declines due to natural mortality, $M$; after recruitment, the number declines due to both natural and fishing mortality, $F$. Total weight of each year class of a species at time $t, W_{t}$, is a function of number of surviving individuals and their length, which is a function of time, up to a maximum life span, $t_{\max }$. An individual's weight in turn is a function of length. Catch is the species-specific fishing morality rate times the biomass; and total catch from legal age size class $k$ through its remaining life span is:

$$
C_{k}=\sum_{t_{k}}^{t_{m i x}} F N\left(t_{R}\right) W_{t}(1-M-F)^{\left(t-t_{R}\right)} \text { for } \mathrm{k}>\mathrm{R}
$$

where $t_{\max }$ is the maximum age for the species, and:

$$
C_{k}=\sum_{t_{k}}^{t_{\max }} F N\left(t_{R}\right) W_{t}(1-M-F)^{\prime} \text { for } \mathrm{k} \leq \mathrm{R} \text {. }
$$

Recovery is presumed to start at the end of the 18-month disposal period. Recovery for each age class occurs in sequence over time as the initial age class matures and grows, with full recovery of the population occurring after $t_{\max }$ years. The loss during this recovery period is the long-term effect: what would have been caught from age classes lost during the recovery period in the absence of disposal. Note that potential disposal sites were screened by the USACE so that the material being disposed of is similar to the sediments at each site, by that facilitating recovery of the same species at the site.

For each species, estimated lost catch is divided into either lost commercial or recreational catch using estimates of commercial and recreational rates by species category. Thus, the overall fishing mortality rate (percent of fish caught per period), $F$, can be decomposed into a commercial and recreational part: $F=F_{\text {Сомм }}+F_{\text {REC }}$. The lost catch is then valued using appropriate commercial or recreational marginal values, as described later. Fishing effort is assumed not to change due to disposal. 
This assumption is reasonable, given the relatively small area impacted (300-430 acres or 121.4 - 174.0 hectares in the Bay; 530 acres or 214.5 hectares for offshore areas) and the fact that the annual lost catch of any species is quite small and widely dispersed, for mobile species.

Commercial values used in the model are the dockside prices for each species (National Marine Fishery Services (2000)). Details are given in (Grigalunas, Opaluch, and Luo, 2001). Assuming effort is constant, market prices represent the marginal economic loss from reduced commercial landings. The estimate of lost recreational values also uses marginal values, as we describe later. All monetary values are in 2002 constant dollars, and a discount rate of $6.87 \%$ is used, the rate designated for use by the USACE for the project studied and reflects the real, federal (risk free) long-term cost of borrowing capital at the time.

The indirect effect measures biomass not produced as a result of a loss of lower trophic organisms, which serve as food resources for commercial and recreational species. Following Applied Science Associates, Inc., et al. (1996), the food web loss for commercial and recreational species is estimated using a simple assumption that loss of biomass for consumer species is proportionate to losses of prey production. However, no food web losses would occur if consumption of all food resources by predator species occurs on-site, since all predator species within the disposal area are also lost due to disposal. Thus, if all lower trophic production is consumed on site, the assumed total loss of all consumer species negates food web losses, so that adding indirect losses to direct losses double counts losses from disposal.

However, off-site food web losses may occur if food resources are lost to consumer species outside the disposal area. For example, consider food resources that are transported by currents. All harvestable fish production within the disposal area is lost, and additional production is lost outside the disposal area due to loss of food resources from the disposal area. Hence, there may be a net loss in production of commercial and recreational predator species outside the disposal area due to mortality to food resources within the disposal area. Consistent with our intent to overstate losses, we assume a net loss in lower trophic production export of 50 percent of the food resources for the proposed disposal sites. Our assumption of proportionate losses of consumer species implies that the off site food web effect equals 50 percent of the biomass in the disposal area for all commercial and recreational species in the adjacent area. Food production is assumed to fully recover immediately following the end of the 18 -month disposal period.

Biological Data. To implement the above model, considerable biological information is needed. This includes information on the abundance of each species (in grams wet weight) at the disposal sites and species-specific parameters for growth in length, weight as a function of length, time to recruitment (i.e., entry) to the legally harvestable fishery, maximum age for each species, natural mortality, and commercial and recreational fishing mortality. (Details are given in Grigalunas, Opaluch, and Luo, 1999).

Two principal sources were used for biological information. One was the Natural Resource Damage Assessment Model for Coastal and Marine Environments (NRDAM/CME) published by the U.S. Department of the Interior (Applied Science 
Associates et al, 1996). The model is incorporated in federal regulations and has been subject to an extensive public review process (NOAA, 1996) Information from this source includes, for each species group: average biomass per unit area, natural and fishing mortality rates, growth, weight as a function of length, years to recruitment, and maximum life. Of course, data in the NRDAM/CME are averages and hence are only approximations.

The second important source of biological data is the Environmental Impact Statements (EIS) prepared for the Providence River dredging project by the USACE $(1998,1999)$. Key information from these sources includes sampling data for finfish, lobster, and mollusks for all potential disposal sites. These data show considerable variability in biomass, by species, among sites.

The data in the EIS is for Catch Per Unit Effort (CPUE), for example, catch per tow for finfish or catch per trap for lobster, and not biomass per square kilometer, which is needed in our model. Data from the NRDAM/CME was employed to provide estimates of biomass per unit area, and the CPUE data from the EIS was used to calibrate the data at each site. Sampling data reported on in the USCE EIS (1999) found many species of fish at the disposal sites. However, a relatively small number of commercial or recreationally important species dominate the sampling data. Hence, the bio-economic analysis focused on these species. Remaining species were aggregated into an "All Other Species" category.

The estimates of average biomass per unit area for each species group given in the NRDAM/CME vary by type of environment (e.g., sand-mud bottom or rocky bottom) as well as seasonally (except for mollusk and lobster). In keeping with our overstated cost approach, we use the highest seasonal biomass estimate given in the NRDAM/CME database to characterize biomass of each species per unit area for each site. Given the biomass per unit area from the NRDAM/CME database, we can estimate total biomass for each site by multiplying the estimates of biomass by area times the total affected area for each site. The estimated area covered by the disposal mound of sediments ranges from 300 to 430 acres (121.4 - 174.0 hectares) in Narragansett Bay to 530 acres (214.5 hectares) in Rhode Island Sound (USACE, Appendix R, 2001).

As mentioned above, the NRDAM/CME uses averaged data for each species and environment type. To reflect site-specific variations in abundance among potential disposal sites, we calibrate the NRDAM/CME biomass estimate for each species to reflect available site-specific fisheries data. For this purpose, species-specific sampling data given in the USCOE EIS (1999) was used to develop calibration factors. To reflect different environments (an estuary versus an offshore sound), two calibrations are done, one for Narragansett Bay sites and one for Rhode Island Sound sites (Grigalunas, Opaluch and Luo, 2001).

Economic Data. Economic data includes the landed price for lost commercial catch of each species and the recreational value for reduced catch by anglers. Commercial prices for each species were obtained from the most recent NMFS landings statistics for ex-vessel prices (NMFS, 2000). A weighted average was used for cases with sub-species and for "All Other Species". In the case of mollusks, considerable variation in the size distribution of mollusks exists between sites, and 
price varies substantially by size. In this special case, we estimated a weighted price using price data from three area seafood wholesalers and converted numbers of mollusk of different sizes to biomass using growth information given in (USCOE 1998, 1999).

Recreational values are based on benefit transfer, using averaged values for catch by mode of fishing, taken from the open environmental and resource economics literature and summarized in the NRDAM/CME (Applied Science Associates et al, 1996). Relevant average values for the study area are $\$ 9.43 / \mathrm{kg}$ for shore-based fishing and $\$ 13.82 / \mathrm{kg}$ (in 2002 dollars) for coastal boat fishing. Species were assigned to appropriate modes; the All Other Species category is assigned a weighted average of constituent species.

\section{Results}

Base Case. Selected results are given in Tables 2 and 3. Constant 2002 dollars are used and the prevailing rate used by the USACE for port projects $(5.875 \%)$ is used for discounting. We reemphasize that these "base case" results are overstated costs given the many conservative assumptions that were used throughout the analysis.

Key results can be summarized as follows. Incremental costs range from \$2.6 million for site 158 in Narragansett Bay to $\$ 0.42$ million for Site 16 in RI Sound (Table 2). These losses include short-term, long-term, and indirect (ecological-i.e., food web) losses for commercial and recreational fisheries. Losses for all Narragansett Bay sites (\$2.2 - \$2.6 million) are considerably higher than for RI Sound sites (\$0.42 - \$0.63 million). Given the data uncertainties involved, we cannot strongly distinguish between sites in the Bay, nor can we easily distinguish between sites within the Sound.

For all potential sites, long-term effects are considerable-more than two-thirds of the total cost (Table 2). This emphasizes the importance of using a cohort-type framework to capture annual losses due to mortality to different cohorts, including juveniles and young of year. Simulation of losses, as is done in this paper, clearly is a critical method to estimate such losses. This is because most the harmed fish are mobile, and the effect on the populations and catch over time and space of mobile species would be tiny. Hence, it would be impossible to estimate lost annual catch using ex-post information.

The results also show that food web effects are non-trivial for all sites and are half as large as the short-term costs. Hence, the results illustrate the importance of considering food web effects in assessing disposal costs. 
Table 2. Short Term, Long-term and Food Web Effects (in 2002 Dollars)

\begin{tabular}{c||c|c|c|c|c}
\hline Area & $\begin{array}{c}\text { Site } \\
\mathbf{( \$ 0 0 0 )}\end{array}$ & $\begin{array}{c}\text { Short Term } \\
\mathbf{( \$ 0 0 0 )}\end{array}$ & $\begin{array}{c}\text { Long Term } \\
\mathbf{( \$ 0 0 0 )}\end{array}$ & $\begin{array}{c}\text { Food Web } \\
\mathbf{( \$ 0 0 0 )}\end{array}$ & $\begin{array}{c}\text { Total } \\
\mathbf{( \$ 0 0 0 )}\end{array}$ \\
\hline \hline Narragansett Bay & 3 & $\$ 345$ & $\$ 1,670$ & $\$ 173$ & $\$ 2,188$ \\
& 157 & $\$ 455$ & $\$ 1,549$ & $\$ 228$ & $\$ 2,231$ \\
& 158 & $\$ 538$ & $\$ 1,812$ & $\$ 269$ & $\$ 2,619$ \\
\hline Rhode Island Sound & 16 & $\$ 74$ & $\$ 307$ & $\$ 37$ & $\$ 417$ \\
& 18 & $\$ 88$ & $\$ 323$ & $\$ 44$ & $\$ 454$ \\
& $69 \mathrm{~A}$ & $\$ 126$ & $\$ 438$ & $\$ 63$ & $\$ 627$ \\
& $69 \mathrm{~B}$ & $\$ 92$ & $\$ 332$ & $\$ 46$ & $\$ 471$ \\
\hline
\end{tabular}

Recreational losses (not shown here to economize on space) exceed commercial losses for Bay sites and are considerable but less than commercial losses in all cases (more than 20 percent of total losses). The high recreational losses for Bay sites are due to (1) large mortality to a recreational species (tautog) for which the Bay is a nursery area, and (2) the relatively high marginal recreational fishing values as compared with marginal commercial values. The estimated high recreational losses underscore the significance of including this category of losses in economic assessments of disposal costs.

Sensitivity Analyses. Sensitivity analyses considered: (1) a larger size of the impact area, (2) delayed habitat recovery, (3) larger food web effects, (4) use of a lower discount rate, and (5) a combination of (1) - (4) (Table 4). Only one factor at a time is varied (all other base-case data are maintained) so that the effect of a particular change can be highlighted. The exception is the "All-Sensitivity-Conditions" case, which assesses simultaneous changes in all sensitivity factors.

Key results of the sensitivity analyses include: First, Bay sites continue to have substantially higher costs ( $\$ 3.8$ million - $\$ 4.8$ million) than Rhode Island Sound sites (\$0.76 - \$1.15 million) in all sensitivity cases. Second, the relative ordering among individual Bay sites changes slightly across sensitivity cases. Again, it is difficult to distinguish between sites within each of the two areas, given the many uncertainties involved (although sites 158 and 69A appear to have higher somewhat higher costs). For the ranges considered, increases in the size of the disposal mound and delays in recovery have the largest effect on costs. Hence, these issues may merit additional attention when evaluating in detail site disposal options. 
Table 3. Sensitivity Analyses for Total Commercial and Recreational Losses in 2002 Dollars (thousands)

\begin{tabular}{|c|c|c|c|c|c|c|c|}
\hline Area & Site & $\begin{array}{c}\text { Base Case } \\
\text { Result } \\
\text { Mound }\end{array}$ & $\begin{array}{c}25 \% \\
\text { Increase } \\
\text { in Size of } \\
\text { Recovery }\end{array}$ & $\begin{array}{l}1 \text { Year } \\
\text { Delay in } \\
\text { Habitat } \\
\text { Rate }\end{array}$ & $\begin{array}{c}3 \% \\
\text { Discount } \\
\text { Export }\end{array}$ & $\begin{array}{c}100 \% \\
\text { Food } \\
\text { Resource } \\
\text { Conditions }\end{array}$ & $\begin{array}{c}\text { All } \\
\text { Sensitivity }\end{array}$ \\
\hline \multirow{3}{*}{$\begin{array}{c}\text { Narragansett } \\
\text { Bay }\end{array}$} & 3 & $\$ 2,188$ & $\$ 2,734$ & $\$ 2,393$ & $\$ 2,462$ & $\$ 2,360$ & $\$ 3,796$ \\
\hline & 157 & $\$ 2,2231$ & $\$ 2,789$ & $\$ 2,546$ & $\$ 2,485$ & $\$ 2,459$ & $\$ 4,083$ \\
\hline & 158 & $\$ 2,619$ & $\$ 3,273$ & $\$ 2,992$ & $\$ 2,914$ & $\$ 2,888$ & $\$ 4,799$ \\
\hline \multirow{4}{*}{$\begin{array}{l}\text { Rhode Island } \\
\text { Sound }\end{array}$} & 16 & $\$ 417$ & $\$ 521$ & $\$ 464$ & $\$ 482$ & $\$ 454$ & $\$ 758$ \\
\hline & 18 & $\$ 454$ & $\$ 568$ & $\$ 513$ & $\$ 517$ & $\$ 498$ & $\$ 833$ \\
\hline & $69 \mathrm{~A}$ & $\$ 626$ & $\$ 783$ & $\$ 713$ & $\$ 708$ & $\$ 689$ & $\$ 1,154$ \\
\hline & $69 \mathrm{~B}$ & $\$ 471$ & $\$ 588$ & $\$ 533$ & $\$ 532$ & $\$ 517$ & $\$ 861$ \\
\hline
\end{tabular}

\section{External Cost of Marine Dredged Sediment Disposal from Proposed Container Port}

For the proposed container port, planned disposal was for an estimated 3 million cubic yards of clean dredged material in area 69B in Rhode Island Sound (RKJA). From Table 3, the base-case cost to fisheries - the shadow price - of marine disposal at $69 \mathrm{~B}$ is estimated to $\$ 0.094$ per cubic yard ( $\$ 471$ thousand/5.1 million cubic yard), while the "worst case" (All Sensitivity Conditions) estimated damages for site 69B is $\$ 0.169$ per cubic yard (\$861 thousand/5.1 million cubic yard).

Hence, the implied cost to fisheries from marine disposal of 3 million cubic yards of dredge material from the proposed case study port ranges from is $\$ 282$ thousand for the fisheries base case to $\$ 507$ thousand for the fisheries worst case. Note that the cost of disposal would be some five times larger, if the dredge disposal occurred at any of the sites within the Bay. In sum, the results presented here show that the choice of disposal sites is an important determinant of dredge disposal costs and quantification of environmental costs can aid in making such decisions ${ }^{10}$.

\section{Air Emissions Associated With Port Development}

\section{Introduction and Background}

Air pollution is a serious issue throughout the Northeast US, as well as in much of Korea, and any potential for further degradation of air quality is an important environmental concern. Pollution exceeding ambient thresholds concentration (Table

${ }^{10}$ The USAE in fact selected site 69B for disposal of clean dredge sediments from Providence River and Harbor. This site has far lower costs to fisheries than Bay sites, but sites $69 \mathrm{~A}$ and 16 in particular have lower costs to fisheries (site 18 has essentially the same costs as 69B). The choice of $69 \mathrm{~B}$ as the disposal site for the Providence River case might reflect transportation cost difference between sites or other costs or considerations beyond the scope of our study. 
5) can limit visibility, harm human health, deteriorate materials, housing, and car exteriors, and cause mortality to plant life and trees (see Appendix B). Human health effects include morbidity and premature mortality. Morbidity encompasses restricted activity days (no strenuous outside activities) or symptom days (cough, headaches, asthma attacks, or irritated throat) (Cropper and Freeman, 1991). Atmospheric depositions also can harm coastal water quality and ecosystem productivity, for example, through nitrogen inputs to estuaries (EPA, 2002; TETRA TECH, 2001; Grigalunas, et al., 2003).

A rich literature examines the consequences of air pollution in general (e.g., McCubbin and Delucchi, 1999; Rowe, et al., 1995; Adams and Crocker, 1991; and Cropper, 2000). A smaller body of work addresses air pollution resulting from marine vessels and container port-related activity in particular (for example, Corbett and Fischbeck, (2002), Bomba, (2002), RK Johns and Associates, (2000), EIS Containerization International (2002). However, few studies integrate emissions to container port activity over time with an economic framework.

Clearly, linking port-related air emissions to damages is complicated. As noted earlier, major port-related activities and resultant incremental emissions must be estimated for each pollutant from each key source, such as truck and train trips. This requires estimates of not only future activity through a port but also the multimodal transportation (train-truck) split. A related complication arises because sources studied are mobile so that the miles traveled, routes, and speed (which affects emissions/mile) should be considered.

Another important set of concerns are regulations controlling air pollution, and as we show below, the implementation of air pollution control regulations substantially affects estimated emissions. Finally, to estimate incremental emissions, air emissions from the alternative use of the industrial park lands earmarked for the port (i.e., the without port case) should be considered.

This section provides estimates of incremental air emissions and potential external costs because of the proposed container port. First, a brief background and overview of the methods used are provided. Then, the data and assumptions are described. Recognizing the many factors and numerous uncertainties involved, a generally conservative, overstated cost approach is used. Sensitivity analyses also employed to show how alternative values for key uncertainties variables might alter the estimates of external costs.

In the United States, air emissions are controlled under the Clean Air Act (CAA). Six principal air pollutants, referred to as Criteria Air Pollutants, are the focus of CAA regulations: carbon monoxide $(\mathrm{CO})$, lead $(\mathrm{Pb})$, nitrogen dioxide $\left(\mathrm{NO}_{2}\right)$, ozone $\left(\mathrm{O}_{3}\right)$, particulate matter (PM), and sulfur dioxide $\left(\mathrm{SO}_{2}\right)$. These six pollutants have been singled out by the US Environmental Protection Agency (EPA) (and the Ministry of the Environment in Korea) because of their potential to cause harm to people, property, and the environment.

Of these six, three $\left(\mathrm{CO}, \mathrm{NO}_{2}\right.$ and $\left.\mathrm{SO}_{2}\right)$ result solely from direct emissions from a variety of mobile (for example, trucks, cars, trains, construction equipment) and stationary sources, for example, power plants, factories, and refineries. Of the remaining two, PM also can result from direct emissions, but is commonly formed 
when emissions of nitrogen oxides $\left(\mathrm{NO}_{x}\right)$, sulfur dioxides $\left(\mathrm{SO}_{2}\right)$, ammonia, and other gases react in the atmosphere. Ozone $\left(\mathrm{O}_{3}\right)$ is not directly emitted, but it is formed when $N O_{x}$ and volatile organic compounds (VOCs) (largely from motor vehicles) react in the presence of sunlight. Ozone is of particular concern during the summer months.

The six pollutants listed above are regulated through the development of healthbased criteria (science-based guidelines) in order to set permissible exposure levels. National air quality standards for each criteria air pollutant are set by the EPA and implemented by each State in the US. EPA's counterpart in Korea, the Ministry of Environment, sets similar air quality standards in Korea.

Port-related air emissions from several sources (Figure 2). Quantification of the emissions and the potential external costs imposed are examined below. We focus on $H C$ and $N O_{x}$ because they are important precursors to ozone. $\mathrm{CO}$ affects global warming and, according to USEPA more than $75 \%$ of nationwide $C O$ emissions are coming from transportation sources, highway mobile sources in particular. $P M$ is not considered specifically since it is not included as an output in the air pollution model (EPA's Mobil 5b) from which pollution coefficients were derived for this project ${ }^{\prime \prime}$. Lead is no longer allowed in the fuels used by the sources studied.

Offsetting effects must be considered. For example, emissions will increase with port growth but emissions per mile will fall because of the phased implementation of EPA's air emission regulations on heavy-duty diesel trucks, the major potential source of air emissions. We include both the growth in traffic and the phasing in of national air pollution regulations for container port-related heavy-duty truck sources under the Clean Air Act, which allows us to sort out the net effect of these two opposing trends ${ }^{12}$.

Two criteria are used to assess the importance of potential air emissions from port development. First, estimated annual emissions are compared with the baseline - the without-port level of air emissions. Simply stated, a projected increase in emissions of 0.1 percent over baseline levels is of less concern than ancrease of, say, 10 percent, all else being equal ${ }^{13}$. Second, the magnitude of potential incremental air pollution external costs are illustrated, drawing upon estimates of damages per ton of emissions in the literature

\footnotetext{
"However, $P M$ is included in the estimates of damages per ton of $N O_{x}$ from the Office of Management and Budget (2003) which we employ later as a form of benefit-transfer.

${ }^{12}$ Overall emissions will be overstated in the paper to the extent that a port at Quonset would partially substitute for road transportation by truck from another port in the without-port case

${ }^{13}$ Even a relatively small percentage increase in aggregate emissions might cause harmful localized effects due to elevated exposure in selected situations (e.g., areas with a high population concentration of elderly).
} 
Figure 2. Simplified Depiction of Emissions by Source for Proposed Container Port

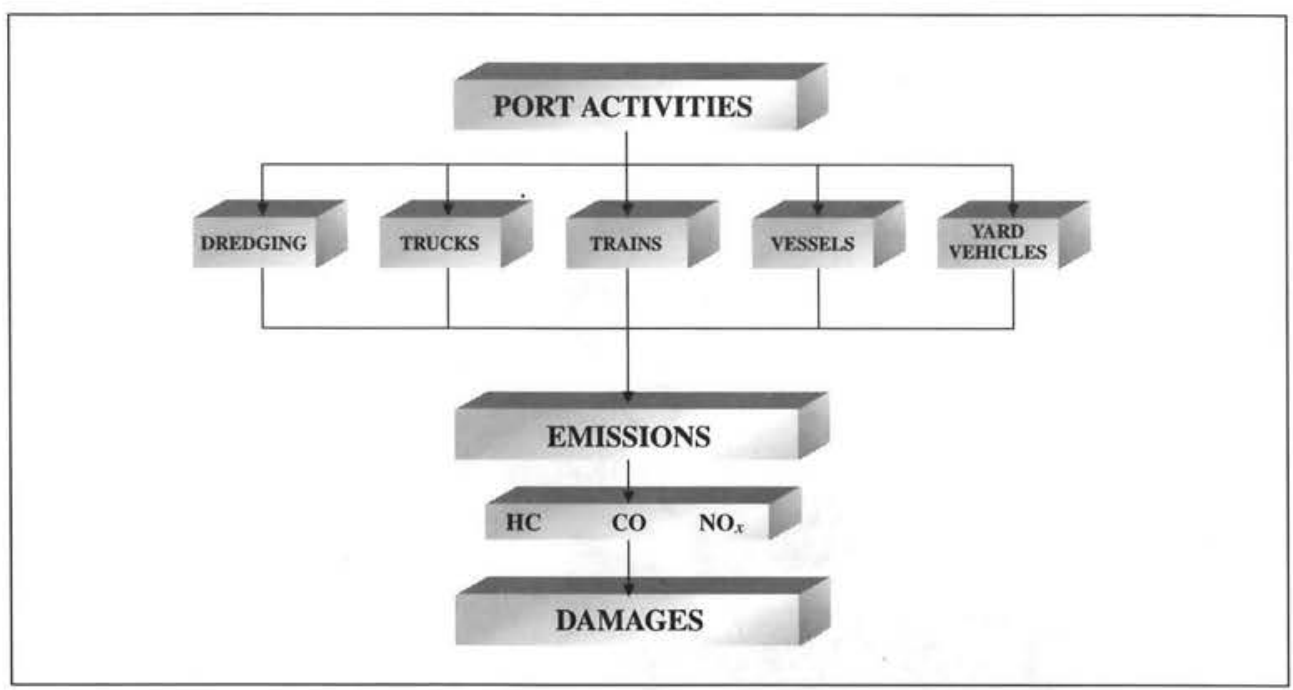

To reflect the geographic distribution of potential air pollution emissions, two areas are distinguished. One is Washington County, Rhode Island, which contains the site of the proposed port. The second is the State of Rhode Island as a whole, recognizing that container traffic will move throughout much of the state, and air emissions around the port may be transported over a broad area (Figure 3). Pollution caused by the port also might affect other states, but our interest here is restricted to effects within the State of Rhode Island ${ }^{14}$.

During port operations, all emissions are from mobile sources. Area-specific emission coefficients for heavy-duty trucks (the major potential pollution source) are adopted from an application of the Environmental Protection Agency's air pollution model, Mobile 5b. Emissions per mile traveled for heavy trucks are a non-linear function of speed, particularly for $C O$ and $N O_{x}$. The rate of emission of a pollutant $j$ (say, $N O_{x}$ ) per mile traveled by a heavy truck, $e_{j}$, can be expressed as a function of speed:

$$
e_{j}=\alpha_{0}+\alpha_{1}(m p h)-\alpha_{2}(m p h)^{2}
$$

where the $\alpha$ 's are the technical links between speed and vehicle emissions of $N O_{x}$ per mile (Figure 5). Thus, $e_{j}$ at first decreases with speed, reaches a minimum, and then begins to increase. Emissions by truck per hour while idling (that is, $e_{j}=\alpha_{0}$ at $\mathrm{mph}=0$ ) also are included, recognizing that emissions while waiting can occur at ports or on congested roads ${ }^{15}$.

\footnotetext{
${ }^{14}$ Ongoing research will address emission offsets in a regional context via the ongoing and proposed use of barges as a substitute for trucks relied upon to move containers in the Northeast (Reiklefs and Ellis, 2001)).

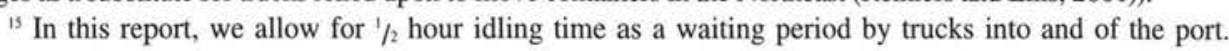
(Emissions due to road congestion could also occur but raise complicated issues outside the scope of this report.)
} 
Figure 3. Rhode Island and Proposed Container Port Area

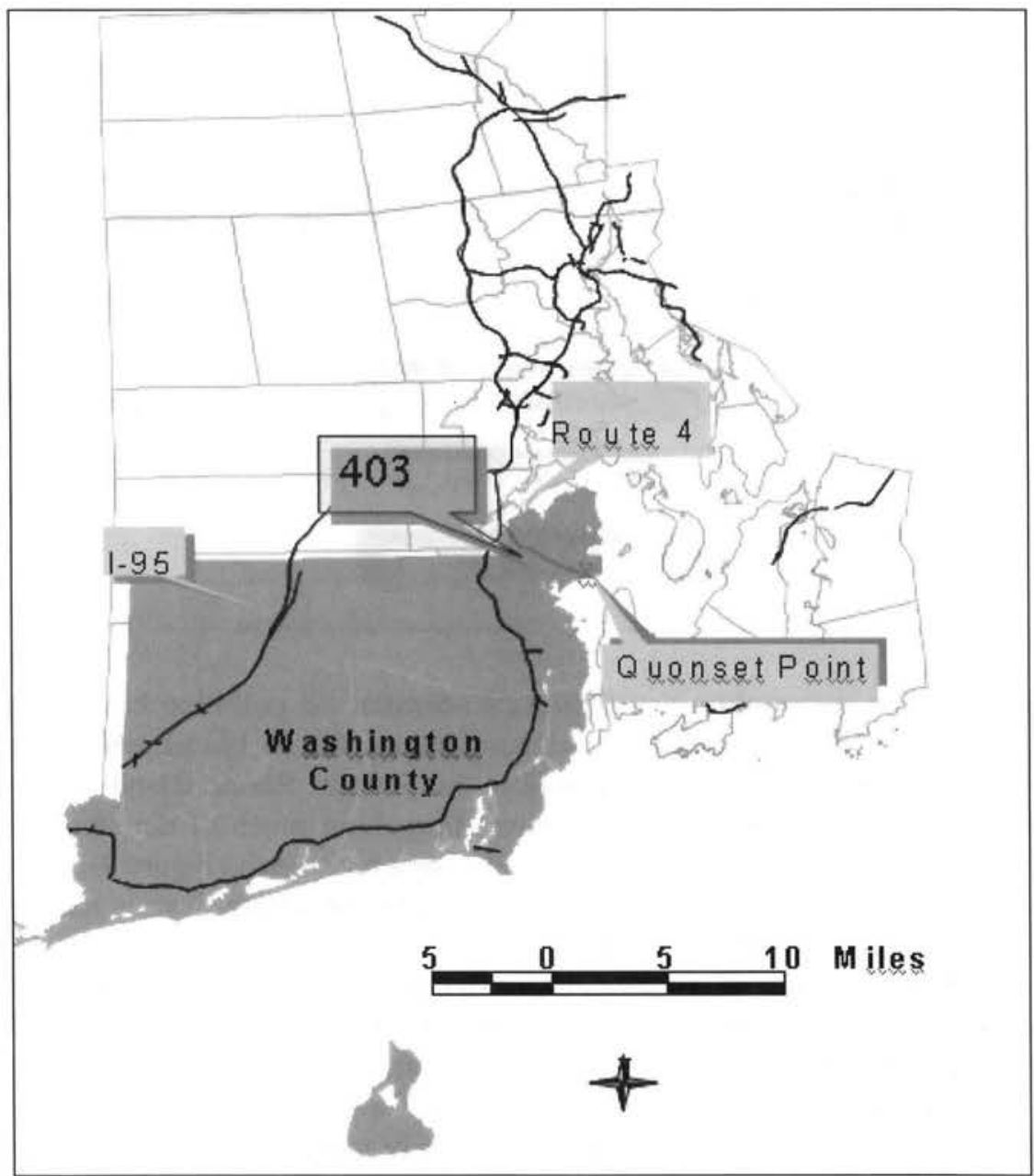

In order to be successful, the planned hub port requires ready access to a Class I (national) rail connection with double stacking capability between Quonset Point and Mid-west markets. The proposed port was premised on this rail access. Given this access, the model simulation results show that the least-cost modal mix for moving containers is 70 percent by train and 30 percent is sent by truck ${ }^{16}$. The simulation model results also show the least-cost routing of trucks serving the port, information important for our assessment of air emissions (Figure 6).

${ }^{16}$ These results are similar to the conclusions of RK Johns \& Assoc. (2000) ("RKJA"), although RKJA's analysis did not involve a formal intermodal analysis and instead was based on expert judgment. Another study, by Quonset Point Partners (1999), also estimated about 70\% of containers would move by train. 
Figure 4. Simplified Depiction of Logic of Air Emission Case Study

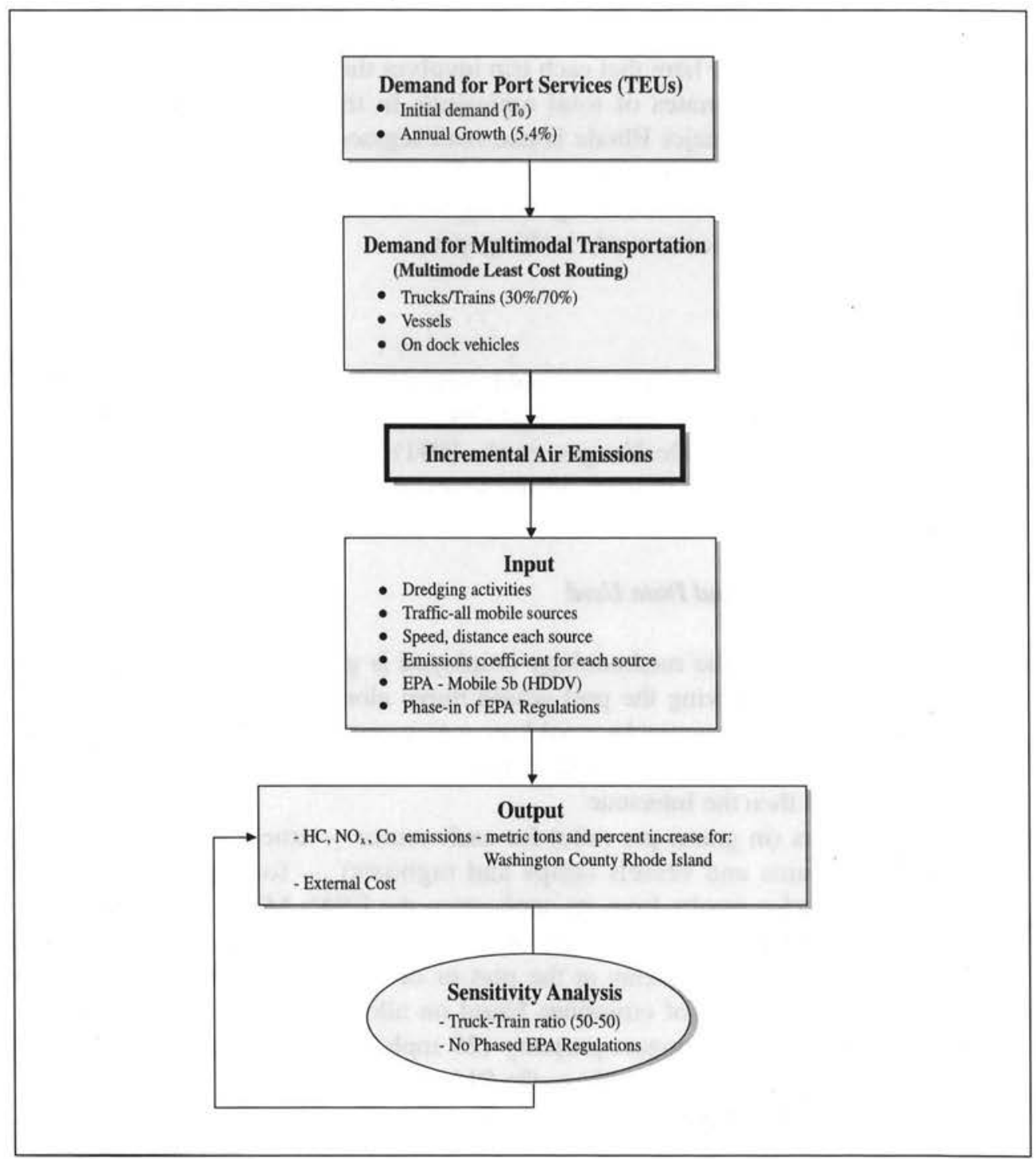

To estimate truck emissions of pollutant $j$, we account for emissions while moving and while idling. The estimated number of truck trips per period $\mathrm{t}$ is $T_{t}$, and the miles traveled on least-cost routes at speed $\mathrm{s}$ in time $t$ is $M_{s t}$. The emission coefficient for pollutant $j$ for each vehicle type is a function of speed and other vehicle characteristics, $c, e_{j s c}$, and the emission coefficient for idling in grams per hour $h$ is $e_{j s c}$ for a given period per trip, I (in hours). Hence, the total estimated emissions of pollutant $j$ at time $t$, Ejt, other things being equal (for example, congestion and weather) is: 


$$
E_{j t}=\left[\sum_{s}\left(e_{j s c} \times M_{s t}\right)+e_{j h c} \times I\right] \times T_{t}
$$

assuming for simplicity here that each trip involves the same speed and number of road miles. Actual estimates of total emissions in the report use road-specific distances and speeds for major Rhode Island road segments along the least-cost road routes estimated in the container port and related intermodal demand simulation model. As noted, emissions occurring outside of Rhode Island are ignored in the quantifications of external costs made in this paper.

\section{Damages}

Valuation of air pollution damages could proceed along several lines, depending upon the availability of data, resources and other factors (e.g., Freeman, 2003). In this paper, benefit transfer (DesVouges, et al., 1991) is used for illustrative purpose concerning air pollution damages, adopting estimates from another source, as described below.

\section{Overview of Methods and Data Used}

The general logic of the methodology employed is given in Figure 4. Here we note that while trucks serving the port would move along several major routes, the model results show that most trucks would use a new connector road between the port and Interstate 95 (Figure 3). As a simplification, all truck trips are assumed to use the connector road and then the Interstate.

Emission factors (in grams per mile) for each source - trucks, on-dock vehicles ("yardhorses"), trains and vessels (ships and tugboats) - for each pollutant are employed. For trucks, results from an application the EPA's Mobile 5b model were used (Figure 5) ${ }^{17}$. Emission rates also are included for idling vehicles, assuming each trip involves a one-half hour delay at the port or on state roads. For the least-cost route, estimates were made of emissions based on allowable road speed at the port facility $(15 \mathrm{mph})$, on the Quonset property $(25 \mathrm{mph})$, on the connector road (37.5 $\mathrm{mph}$ ) and Interstate highway ( $55 \mathrm{mph}$ ) to the RI border ${ }^{18}$.

The baseline (without-port) emissions against which we compare potential portrelated air emissions are for 1999, the most recent year for which emission data could be obtained. Incremental emissions from the port are quantified by reducing estimated emissions from port-related activities the with-port case) by estimated emissions from alternative uses of the 200 acres of industrial park which had been earmarked for the port (the without-port case). To do this, we assume that the traffic

\footnotetext{
${ }^{17}$ We acknowledge Mr. Ron Marccacio of EPA who provided the Mobile 5 b results used in this report.

18 The legal speed for the connector road is $25 \mathrm{mph}$ but the actual speed is anticipated to be between 35 $40 \mathrm{mph}$, according to the North Kingstown Police Department. We use $37.5 \mathrm{mph}$. All other road speeds are set at the legal speed limits.
} 
per acre for this area is the same as estimates of the current per acre traffic for the entire facility site (Table 5). The without-port traffic is assumed to remain the same over the entire 20-year operating period.

Figure 5. Emissions of $\mathrm{HC}, \mathrm{CO}$ and $\mathrm{NO}_{x}$ from Heavy Duty Trucks as a Function of Speed

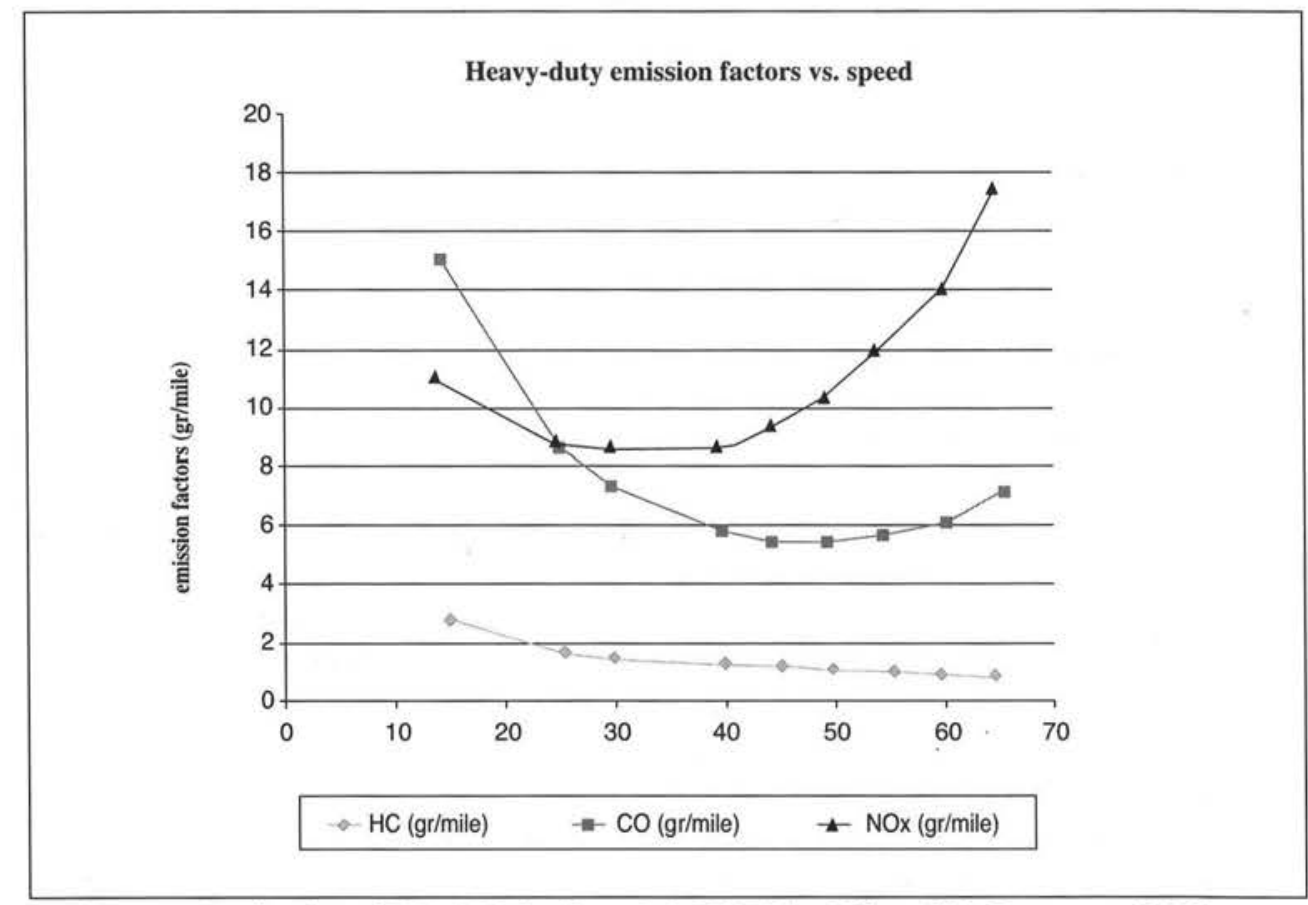

Source : Application of EPA Mobile 5b model (US EPA, Office of Air Resources, 2002)

Table 4. 2002 Heavy-duty diesel emission factors vs speed (Mobile 5b)

\begin{tabular}{c||c|c|c}
\hline SPEED $(\mathbf{m p h})$ & HC $(\mathrm{gr} / \mathbf{m i l e})$ & $\mathbf{C O}$ (gr/mile) & NO (gr/mile) \\
\hline \hline 5 & 4.19 & 30.5 & 15.54 \\
\hline 10 & 3.29 & 20.72 & 12.89 \\
\hline 15 & 2.64 & 14.95 & 11.08 \\
\hline 20 & 2.17 & 11.29 & 9.84 \\
\hline 25 & 1.82 & 8.92 & 9.11 \\
\hline 30 & 1.56 & 7.38 & 8.71 \\
\hline 35 & 1.36 & 6.39 & 8.63 \\
\hline 40 & 1.22 & 5.79 & 8.86 \\
\hline 45 & 1.12 & 5.49 & 9.43 \\
\hline 50 & 1.05 & 5.45 & 10.39 \\
\hline 55 & 1.01 & 5.66 & 11.86 \\
\hline 60 & 0.98 & 6.15 & 14.04 \\
\hline 65 & 0.98 & 6.99 & 17.21 \\
\hline Idle & $4.64 \mathrm{gr} / \mathrm{hr}$ & $35.31 \mathrm{gr} / \mathrm{hr}$ & $16.91 \mathrm{gr} / \mathrm{hr}$ \\
\hline
\end{tabular}

Source : US EPA, Office of Air Resources, 2002 
Table 5. Baseline - Traffic Volume on the Connector Road by Vehicle Types

\begin{tabular}{l||c|c}
\hline \multicolumn{1}{c||}{ Vehicle Type } & $\begin{array}{c}\text { Traffic per Day } \\
\text { (Trp) }\end{array}$ & $\begin{array}{c}\text { Traffic per Hour }^{b} \\
\text { (TPH) }\end{array}$ \\
\hline \hline Automobile & 15,180 & 1,265 \\
\hline Medium Truck & 990 & 83 \\
\hline Heavy Truck & 330 & 28 \\
\hline Total & 16,500 & 1,376 \\
\hline
\end{tabular}

Source : 2000 Traffic Flow Map (based on 1999) and 1998 Truck Flow Map (based on 1997), RIDOT.

a: Traffic volumes by vehicle types are calculated using given total number $(16,500)$ and percentage of medium truck $(6 \%)$ and heavy trucks $(2 \%)$.

b: $\mathrm{TPH}=\mathrm{TPD} / 12$

\section{Incremental Air Emissions}

\section{Implementation of New Air Pollution Emissions Regulations}

EPA regulations will substantially reduce, in phases, air emissions from mobile sources, including heavy-duty vehicles, light-duty vehicles, and locomotives. Here we focus discussion on heavy-duty diesel-powered trucks, by far the major potential source of harmful emissions of concern in our research, as we show below.

EPA regulates emissions from large, or "heavy-duty", diesel engines used in trucks. Trucks have been regulated since the mid-1970s with more progressively stringent standards, but compliance rates may vary.

Historically, the target of diesel emission regulations has been new diesel engines. Through a series of progressively more stringent standards, engine emissions have been substantially reduced. Still, phased-in final emission standards (outlined below) for highway heavy-duty vehicles and engines will go much further by setting nearzero emission limits. Reduced emissions of $P M$ and $N O_{x}$ also is encouraged through a Voluntary Diesel Retrofit Program run by EPA, which uses various incentives for states (emission credits) as well as market incentives for businesses.

\section{Alternatives and Key Assumptions Used to Estimate Potential Air Emissions}

In sum, a no-development baseline and two major development alternatives and sensitivity analyses are analyzed below:

- No Port Development (Baseline)

- Use of the 200 acres of Quonset industrial park earmarked for a port is assumed to generate the same traffic per acre is currently generated by developed parts of the park. Air emissions from this traffic are estimated using emission coefficients for each vehicle source.

- "Base Case" Port Development (Table 2):

- startup moves in year 2007 are 316 thousand containers, growing at 5.4\% 
annually

- containers move $30 \%$ by truck and $70 \%$ by train

- EPA air emission regulations on heavy trucks are phased in with $100 \%$ compliance by 2030 .

- Sensitivity Analyses

- Containers moves are $50 \%$ truck and $50 \%$ train

- EPA air emission regulations on heavy trucks are not implemented

- Combined case: containers move $50 \%$ by truck, $50 \%$ by train and EPA air regulations are not implemented

Briefly, the sensitivity analysis using $50 \%$ of moves by truck for a hub port is unlikely because a successful hub port at Quonset would almost certainly require access to Midwest markets, which in turn requires the substantial use of double stacked trains tied into the national rail network. Also, implementation of EPA's Phase I and II reduction on truck emissions appears a foregone conclusion. Hence, the sensitivity analyses presented represent a "worst case" for air emissions.

Five primary sources of transportation emissions are included: dredges, trucks, trains, port utility vehicles, and vessels. All are assumed to be equipped with heavyduty diesel-powered engines, one of the most polluting engines, which also serve to overstate these emissions. Estimated emissions are presented for benchmark years, as noted (Table 1).

To acknowledge spatial and speed issues, annual air emissions are estimated for Washington County and all of Rhode Island. Emissions are the product of each source activity unit, for example, the number of miles by truck at given speeds along least-cost routes (Figure 6), by an associated unit emission factor, such as grams of pollutant emitted per mile traveled for a given speed (see Figure 5) or per gallon of fuel burned for vessels.

In Figure 6, the thicker lines indicate movement of containers on roads. The closer a road is to the hypothetical port at Quonset Point, the "thicker" it will be because of higher annual container movements.

For vessels, Kristensen's (2003) main results were adopted. He shows that emissions are a function of vessel size and speed. For size, we adopt his intermediate case results and assume that arriving container ships on average carry 3000 TEUs. Regarding speed, vessels are assumed to travel the limit for Narragansett Bay, 15 knots per hour, over the 16 mile round-trip distance from the mouth of the Bay to the hypothetical port site at Quonset. The annual emissions thus are a product of the emission factor for each engine by the number of miles for each trip and by the annual number of vessel trips to handle the estimated total containerized cargo. Two tugboats accompany each container vessel (Table 1). 
Figure 6. Annual TEUs Movements on RI Roads

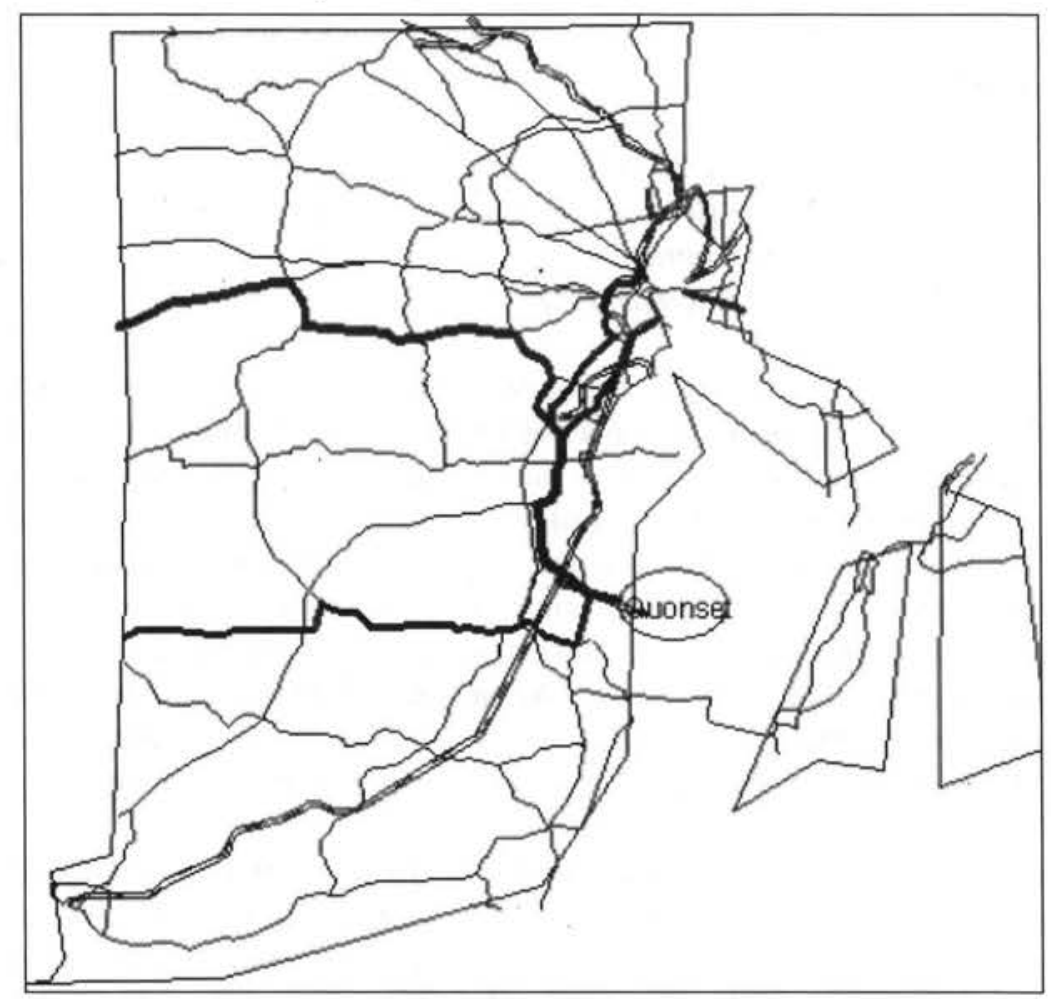

Yard vehicles are assumed (1) to engage in two trips per container move at the terminal site, with each trip involving one mile and (2) to generate the same emission per mile as heavy trucks. These assumptions overstate emissions from this source.

For dredging, we use the ratio of emission per million cubic yards dredged given in an in-depth study for the Port of New York and new Jersey (USACE, 2003). These results show that 45 tons of $\mathrm{NO}_{\mathrm{x}}$ is emitted per million cubic yards dredged. For the case-study port an estimated 8.37 million cubic yards would be dredged (RKJA, 2000) over about two years, with equal volumes assumed dredged each year.

Estimated air emissions from port-related operations will depend upon EPA regulations on emissions. Given the importance of this issue, these regulations and the assumptions used in arriving at our estimates are spelled out in some detail.

EPA regulations on emissions from heavy-duty diesel trucks are to be implemented in two phases, with Phase I starting in 2004. Phase I decreases in emissions per mile are anticipated to be approximately 40 percent. Stricter, Phase II regulations are to take effect in 2006 - 2007, leading to another 90 percent reduction in per mile emissions. According to the EPA, both phases will be fully implemented by 2030 (USEPA, Office of Transportation and Air Quality, EPA420-F-00-026, July 2000).

Since the simulation model assumes operations of the port starts in 2008 (Figure 
1) (Grigalunas, Luo and Jung, 2002), the heavy-duty trucks serving the port will be a mix of today's (2003) "vintage", some meeting Phase I standards, and some meeting the more environmentally demanding Phase II standards. In 2003, all trucks are assumed to meet the then-prevailing standards. Over time, the fleet will have a mix of vehicles ranging from brand new to age 20 , the maximum life of a heavy-duty truck. In each of following years, an equal percent of the vehicles leaves the fleet and is replaced by an equal number of trucks meeting the air emission standard in effect at that time (Figure 7). Emissions per mile in the model vary with the standard met. Again, full compliance with appropriate EPA air emission regulations is assumed.

Figure 7. Rate of Adoption for EPA's Air Emission Regulations on Heavy Duty Trucks

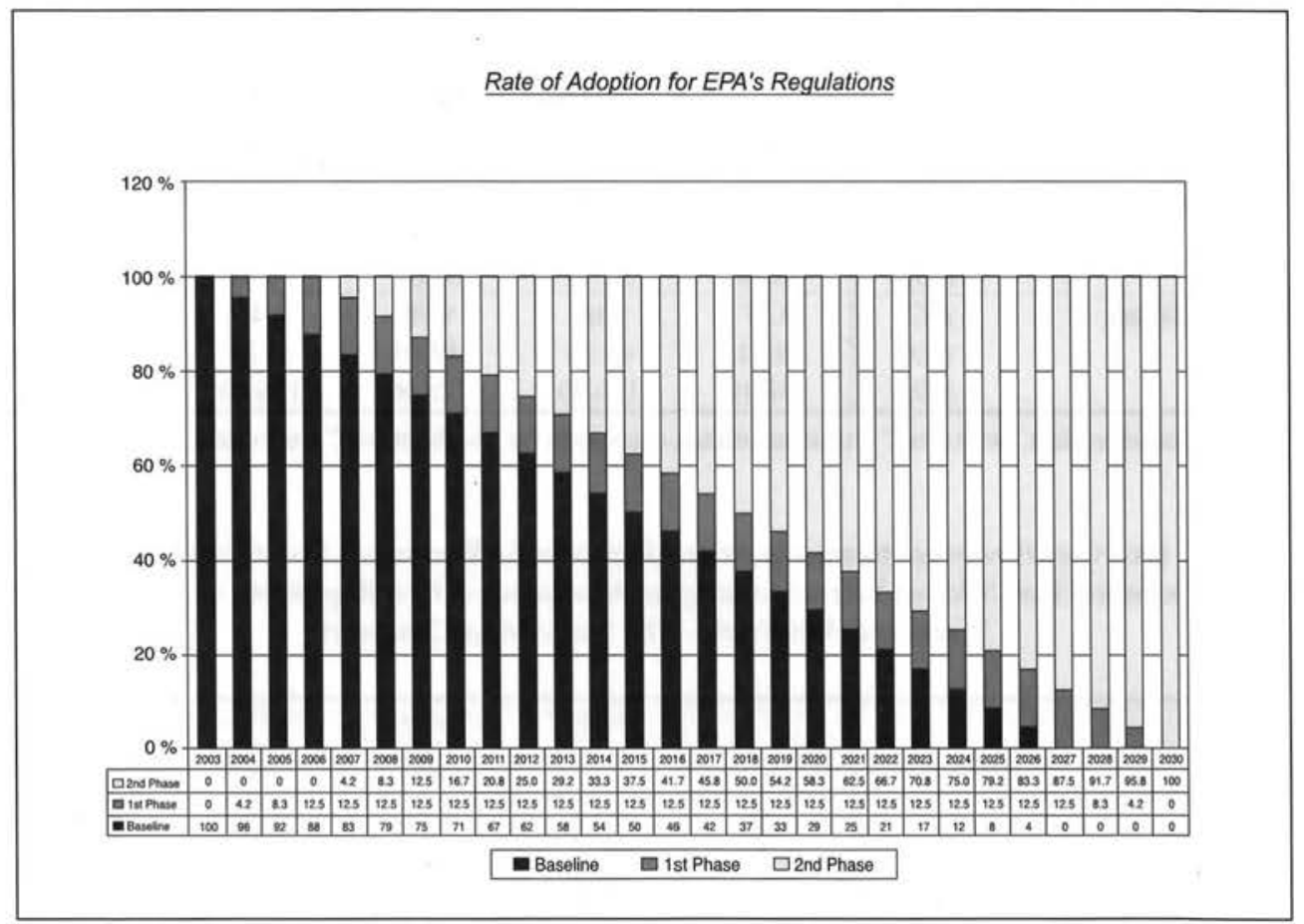

\section{Results}

Key air emission results for the port development Base Case can be summarized as follows:

- $N O_{x}$ is the largest single pollutant from port-related operations and for Rhode Island increases from 108 metric tons (mt) in year 1 to $135 \mathrm{mt}$ in year $20 . \mathrm{CO}$ is the second largest emission (Table 6).

- For the state as a whole, emissions of $N O_{x}$ from the hypothetical port development represent less than a 0.4 percent (that is, 0.004 ) increase over 
baseline emissions for the initial year and a 0.5 percent increase for year 20 (Table 7).

- For Washington County, emissions of $N O_{x}$ represent a $1.1 \%$ increase in year 1 and a $2.7 \%$ increase for year 20 (Table 7).

- Trucks are by far the largest emission source, contributing about two thirds of all emissions (not shown to economize on space).

- Implementation of and $100 \%$ compliance with phased EPA air pollution regulations on heavy duty trucks substantially reduces $N O_{x}$ emissions (Figure 8).

Table 6. Base Case Incremental Annual Emissions for Washington County and Rhode Island for the Hypothetical Port, Selected Years, Assuming Implementation of EPA Regulations on Heavy Duty Trucks and Use of $30 \%$ Truck - 70\% Rail to Move Containers

\begin{tabular}{lc||c|c|c|c|c}
\hline \multicolumn{1}{l}{} & \multicolumn{1}{l||}{} & \multicolumn{1}{c}{ Y*ar } & **** & \\
\cline { 2 - 7 } & Pollutant & 1 & 5 & 10 & 15 & 20 \\
\hline \hline \multirow{2}{*}{ Washington County } & $H C$ & 4.54 & 4.74 & 4.99 & 4.90 & 4.22 \\
& $C O$ & 22.34 & 22.93 & 23.52 & 22.01 & 17.10 \\
& $N O_{x}$ & 45.61 & 51.73 & 61.09 & 71.01 & 81.02 \\
\hline \multirow{2}{*}{ Rhode Island } & $H C$ & 9.37 & 9.66 & 9.98 & 9.44 & 7.52 \\
& $C O$ & 48.31 & 49.15 & 49.70 & 45.21 & 32.68 \\
& $N O_{x}$ & 107.91 & 116.40 & 128.60 & 136.10 & 135.10 \\
\hline
\end{tabular}

"Estimates reflect "with-port" emissions minus emissions for "without port" use of land.

Table 7. Base Case Percentage Increase in Annual Emissions for Washington County and Rhode Island for Hypothetical Port, Selected Years, Assuming Implementation of EPA Regulations on Heavy Duty Trucks and $30 \%$ Truck - $70 \%$ Rail to Move Containers

\begin{tabular}{lc||c|c|c|c|c}
\hline \multicolumn{1}{l}{} & \multicolumn{3}{c}{ **** } & \multicolumn{1}{c}{ Year } & $* * * *$ \\
\cline { 3 - 7 } & Pollutant & 1 & 5 & 10 & 15 & 20 \\
\hline \hline \multirow{2}{*}{ Washington County } & $H C$ & 0.15 & 0.15 & 0.16 & 0.16 & 0.14 \\
& $C O$ & 0.13 & 0.13 & 0.14 & 0.13 & 0.10 \\
& $N O_{x}$ & 1.11 & 1.34 & 1.71 & 2.15 & 2.67 \\
\hline \multirow{2}{*}{ Rhode Island } & $H C$ & 0.04 & 0.04 & 0.04 & 0.04 & 0.03 \\
& $C O$ & 0.02 & 0.02 & 0.02 & 0.02 & 0.01 \\
& $N O_{x}$ & 0.32 & 0.37 & 0.43 & 0.48 & 0.50 \\
\hline
\end{tabular}


Figure 8. Changes in Emissions of $N O_{x}$ influenced by EPA Regulation for Heavy Duty Vehicles for Rhode Island

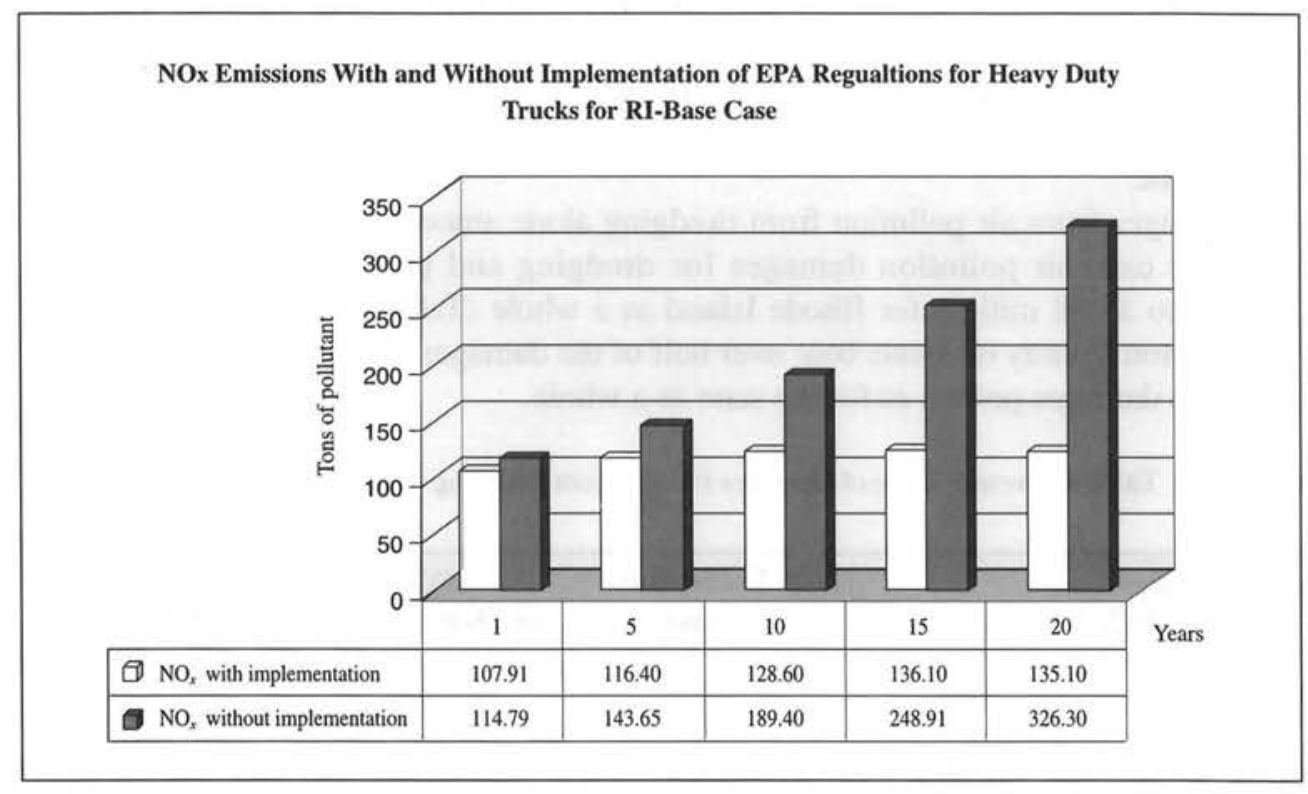

\section{Perspective on the External Costs from Air Emissions}

Information in the recent literature provides some insight into the magnitude of potential damages from air emissions considered in this paper. A survey by Burtaw, et al. (2003) of several studies of $N O_{x}$ and $C O$ emissions from electrical utility plants suggests marginal damages to health of $N O_{x}$ of around $\$ 800$ per ton. However, the Burtaw, et al. survey applies to stationary sources, is for health effects only, and overall is not well suited to reflect the mobile, ground-level sources examined in the research reported on in this paper.

A recent summary of the air pollution damages literature by the Office of Management and Budget (Federal Reg., 2003) is more appropriate for our purposes. It contains results for mobile sources, which are close to the ground and do not disperse and dilute as readily as stationary sources, such as used by utilities considered in Burtaw et al., which tend to use tall smokestacks. Further, the OMB review specifically included the benefits and costs of federal regulations on emissions from trucks under the phased implementation of EPA regulations discussed above. In keeping with the goal of overstating costs when possible, the OMB's inclusive ${ }^{19}$, high estimate of damages per metric ton of emission is $\$ 5,618$ (in year 2002 dollars) is employed to provide perspective on potential damages from port-related air emissions ${ }^{20}$.

\footnotetext{
${ }^{19}$ The OMB results for damages include the effects of $P M$ for which $N O_{x}$ is a precursor.

${ }^{20}$ The major environmental costs in the EPA analysis were for premature mortality. Use of a constant damage implies a linear dose-response function for pollution and harmful effects.
} 
Now, potential air pollution damages from the case study port can be put into perspective. First, we describe air pollution damages from dredging activity alone, which are common to all of the cases assessed. Then, we show the total damages from dredging plus damages from port operations for the base case and the sensitivity analyses for the 20 -year port operating period. For discounting annual damages, a rate of $5.875 \%$ is used, the rate applicable for port projects while this research was being done.

Damages from air pollution from dredging alone amount to $\$ 1.73$ million (Table 8). Base case air pollution damages for dredging and port operations combined amount to $\$ 7.98$ million for Rhode Island as a whole (Table 9). Of these damages, Washington County residents bear over half of the damages (\$3.81 million), assuming the same damages per ton as for the state as a whole.

Table 8. Present Value of Damages for $N O_{x}$ from Dredging Activities (in $2002 \$$ )

\begin{tabular}{l|c|c|c|c}
\hline $\begin{array}{c}\text { Damages/ } \\
\text { Ton of Poll. }\end{array}$ & & $\begin{array}{c}\text { NO } \text { Emissions }^{\mathrm{c}, \mathrm{d}} \\
\text { (tons) }\end{array}$ & $\begin{array}{c}\text { PV } \\
\text { of Damages }^{\mathrm{b}}\end{array}$ & Total PV \\
\hline \hline \multirow{2}{*}{$\$ 5,618^{\star}$} & Year 1 & 188.33 & $\$ 891,476$ & \multirow{2}{*}{$\$ 1,733,483$} \\
\cline { 2 - 4 } & Year 2 & 188.33 & $\$ 842,008$ & \\
\hline
\end{tabular}

a. Source : Federal Register, Vol.68, No.22, Feb.3, 2003

b. Discount Rate $=57 / 8 \%$ (Source: USACE)

c. Total Quantity Dredged = 8.37 MCY (Source: RKJ \& Associates Report, 2000)

d. 45Tons of Pollutant/MCY (Source: Deepening Project, April 2003, US Army Corps of Engineers

- New York District, http://www.nan.usace.army.mil/harbor/pdf/industry.pdf

Table 9. Present Value of Damages from $\mathrm{NO}_{x}$ emissions from dredging and operations: Base Case (30\%Truck-70\%Train) EPA Regulation Implemented (in 2002 dollars)

\begin{tabular}{c|c|c|c|c}
\hline $\begin{array}{c}\text { Damages/ } \\
\text { Ton of Poll. }\end{array}$ & Area & Dredging & $\begin{array}{c}\text { Operations - } \\
\text { Base Case }\end{array}$ & Total PV \\
\hline \hline \multirow{2}{*}{$\$ 5,618 \mathrm{a}$} & Rhode Island & $\$ 1,733,483$ & $\$ 6,244,896$ & \multirow{2}{*}{$\$ 7,978,379$} \\
\cline { 2 - 4 } & Washington County & $\$ 866,742$ & $\$ 2,942,334$ & $\$ 3,809,076$ \\
\hline
\end{tabular}

a. Source : Federal Register, Vol.68, No.22, Feb.3, 2003

\section{Sensitivity Analyses}

Here incremental port-related air pollution and the resulting damages are estimated for several cases using assumption which differ from those in the Base Case results. For emissions we show the worst case, which assumes:

- Trucks move $50 \%$ rather than the $30 \%$ of containers estimated in the Base Case, 
- EPA Phase I and Phase II air pollution regulations on heavy-duty trucks are not implemented, and

- A combined case Trucks move $50 \%$ of containers and EPA regulations on trucks are not implemented (the "Worst Case")

The sensitivity analyses show that:

- increasing the use of trucks from $30 \%$ to $50 \%$ of all container moves has a small percent increase in the air emissions studied.

- failure to implement the Phase I and II EPA regulations of emissions from heavy duty trucks has a more serious effect on the growth of emissions.

- the worst case considered - where Phase I and II EPA regulations on emissions are not implemented and trucks are used to move $50 \%$ of containers has the most serious consequences increases in pollution. In this case, year 20 Washington County emissions exceed baseline levels by $3.26 \%$ and RI emissions increase by $1.27 \%$. As mentioned earlier, this case is considered most unlikely.

Table 10. Sensitivity Analysis: Percentage Increase of Key Pollutants over Washington County and Rhode Island Baseline Emissions for Hypothetical Port, Selected Years, Assuming EPA Regulations on Heavy Trucks are Not Implemented and $50 \%$ Truck - $50 \%$ Rail Used to Move Containers

\begin{tabular}{lc||c|c|c|c|c}
\hline \multicolumn{1}{l}{} & \multicolumn{3}{c||}{} & \multicolumn{2}{c}{ Year } & $* * *$ \\
\cline { 3 - 7 } & Pollutant & 1 & 5 & 10 & 15 & 20 \\
\hline \hline \multirow{2}{*}{ Washington County } & $\mathrm{HC}$ & 0.25 & 0.31 & 0.40 & 0.52 & 0.67 \\
& $\mathrm{CO}$ & 0.23 & 0.28 & 0.36 & 0.47 & 0.61 \\
& $\mathrm{NO}_{s}$ & 1.55 & 1.79 & 2.16 & 2.64 & 3.26 \\
\hline \multirow{2}{*}{ Rhode Island } & $\mathrm{HC}$ & 0.07 & 0.08 & 0.11 & 0.14 & 0.19 \\
& $\mathrm{CO}$ & 0.04 & 0.05 & 0.06 & 0.08 & 0.10 \\
& $\mathrm{NO}_{x}$ & 0.49 & 0.60 & 0.77 & 0.99 & 1.27 \\
\hline
\end{tabular}

Sensitivity analyses for air pollution damages are given in Table 11. Damages range from the Base Case results described above, $\$ 3.8$ million for Washington County to $\$ 7.9$ million for Rhode Island, to the "worst case" damages, for which damages are $\$ 14.9$ million at the state level and \$5.9 million for the County. The biggest change in damages occurs if the EPA's does not implement phased air emission control on heavy duty trucks. Clearly, full implementation of, and compliance with the regulations is important for controlling emissions from the proposed port development. 
Table 11 .Present Value of Damages (in 2002 dollars) for $\mathrm{NO}_{\mathrm{x}}$ from Dredging and Mobile Source Activities for Base Case and All Sensitivity Analyses ${ }^{b \varepsilon}$

\begin{tabular}{c|c||c|c|c|c}
\hline \multicolumn{2}{l||}{} & \multicolumn{4}{c}{$* * *$ Cases Considered *** } \\
\hline \hline $\begin{array}{c}\text { Damage/ } \\
\text { Ton of Poll. }\end{array}$ & $\begin{array}{c}\text { 30-70 EPA's } \\
\text { Reg. } \\
\text { Implemented } \\
\text { (Base Case) }\end{array}$ & $\begin{array}{c}\text { 30-70 EPA's } \\
\text { Reg. Not } \\
\text { Implemented }\end{array}$ & $\begin{array}{c}50-50 \text { EPA's } \\
\text { Reg. } \\
\text { Implemented }\end{array}$ & $\begin{array}{c}50-50 \text { EPA's } \\
\text { Reg. Not } \\
\text { Implemented }\end{array}$ \\
\hline $5,618^{*}$ & Rhode Island & $7,978,379$ & $10,743,531$ & $10,161,904$ & $14,873,724$ \\
\cline { 2 - 6 } & Washington County & $3,809,076$ & $4,556,790$ & $4,696,900$ & $5,969,692$ \\
\hline
\end{tabular}

'Source : Federal Register, Vol.68, No.22, Feb.3, 2003

${ }^{b}$ Discount Rate $=57 / 8 \%$ (Source: USACE)

' Dredging takes place over 2-year period; operations over a 20-year period beginning in year 7.

- Air pollution costs are allocated 50\% Washington County, 50\% rest of RI

In addition to damages from total incremental emissions, the marginal damages per container truck mile are of interest for some purposes, such as assessments of the full social costs of transport modes. The above results allow us to estimate, for example, the shadow price of truck road use per mile for air pollution. This value is given by $\partial D / \partial M=\partial D / \partial E \times \partial E / \partial M$ where $D$ is damages, $M$ miles, and $E$ emissions per mile. Assuming trucks travel 50 miles per hour, and using the emission factors in Table 4 , the cost per mile ranges from $\$ 0.0023$ in the base case considered to $\$ 0.0584$ per mile for the (unlikely) case where air pollution control regulations considered in this report are not implemented.

\section{SUMMARY, CONCLUSIONS, AND QUALIFICATIONS}

Environmental issues are important in port and related inter-modal planning. Estimates of external costs (shadow prices) can contribute to port planning by (1) putting environmental costs and benefits in perspective, (2) expanding the scope of costs included in benefit-cost analyses, and (3) contributing to resolution of sensitive policy issues (e.g., selection of marine dredge disposal sites). Estimates of external costs also can aid in (4) assessing mitigation measures, and (5) more broadly, contributing to estimates of virtual (equilibrium) price for analyzing "greening" of transportation systems so that transportation costs reflect full social costs.

This paper summarizes estimation of external costs for two often-contentious port environmental issues: marine disposal of clean dredged sediments, and incremental air emissions. Estimates of these costs are made in the context of a case study - a planned (but since cancelled) hub container port proposed for Quonset Point on Narragansett Bay, RI.

Estimates of the scale and timing of port development and the annual demand for port services were used to project activities resulting in environmental stresses. Losses to fisheries because of dredge disposal are based on estimates of the amount of 
dredging required, data for alternative proposed marine disposal areas, and use of a bio-economic model.

Emissions of key air pollutants are estimated using pollution intensity coefficients for major port-related sources - trucks, trains, yard vehicles, and vessels. Dredging occurs over a 2-year period, while operations are projected for 20 years following development.

For both external costs, base-case results and several sensitivity analyses were presented. Costs to fisheries from dredge disposal associated with the planned port were assessed using a bioeconomic model which simulates short- and long-run and indirect (food web) fishery losses from the inception of an 18-month dredging period through recovery of the affected fishery resources. Throughout, assumptions were used which overstate these losses. Seven potential dredge sites were analyzed. A disposal site with among the lowest costs to fisheries (69B) was identified as the potential disposal site in the state-funded port planning study (RKJA), and we used this site to estimate external costs for disposal planned for the proposed port.

For potential externalities from air pollution, annual incremental emissions for key pollutants were estimated for trucks, trains, yard vehicles and vessels. To do this, emission coefficients were used for $N O_{x}, C O$, and $H C$. Emissions from heavy duty trucks, the largest pollution source by far, were estimated using the (1) least-cost truck-train split of $30 \%$ truck and $70 \%$ train, (2) least-cost road and train routes, (3) speeds traveled, and (4) annual number of trips. A $5.4 \%$ annual growth in port demand was included, and phasing in of EPA regulations on air emissions for heavy duty trucks was assumed. Benefit-transfer was used to translate metric tons of emissions into damages for Washington County and for the State of Rhode Island as a whole.

Our key results are that the present value of external costs (value of lost catch) to commercial and recreational fisheries from marine dredge disposal at site 69B because of the proposed port are from $\$ 471$ thousand for the base case to $\$ 861$ thousand for a "worst case" in years 2002 dollars. For air pollution, base case costs are $\$ 8.0$ million and "worst-case" results amount to $\$ 14.9$ million. Some $37 \%$ of emissions and hence damages occur in Washington County, which would contain the port.

In total, external costs for these two environmental issues therefore range from $\$ 8.5$ million to $\$ 15.8$ million for the unlikely worst case in present value terms. For perspective, this is equivalent to an external cost per Rhode Island state resident (about 1.06 million people in total, in 2002) of $\$ 8.02$ to $\$ 14.91$ per person from these two externalities.

Despite the use of assumptions that overstate costs, we should acknowledge that several constraints on the analysis unavoidably understate the estimates of costs. For example, our illustration of external costs of air emissions from the port uses a 20year operating period, (starting in year 7) because assessments of externalities beyond 2028 seemed problematic, given available data. Hence, air pollution costs incurred after 20 years of operations were not considered. Also, air pollution damages from emissions beyond Rhode Island borders were not considered, and as a result total emission costs to society are understated. We also remind the reader that only two 
port-related environmental issues are addressed in this paper. Economic costs because of loss of subtidal and intertidal lands, and incremental road noise, for example, are omitted from the paper but examined elsewhere (Grigalunas, Luo and Chang, 2001, and Grigalunas, Trandafir, Kwon and Luo, 2004).

Finally, we should note that the results given here would likely not apply to ports in other countries which do not have strict environmental controls. For example, US regulations of air emissions have substantially curtailed air pollution from heavy trucks, and regulations being phased in will essentially drive these emissions to nearzero levels. Also, lead is no longer emitted from mobile sources. Other countries may not have such restrictive regulations. Hence, the total emissions and their composition per TEU may be substantially greater in such cases.

\section{REFERENCES}

Adams, Richard and Thomas Crocker, 1991. "Materials Damage" in Estimating the Demand for Environmental Quality. New York: North Holland

Anonymous, 2002. "Decline of wood thrush shown linked to acid rain". Natural New England, 13 (fall): p. 27.

Burtaw, Dallas, Alan Krupnik, Karen Palmer, Anthony Paul, Michael Toman, and Cary Boyd, 2003. Ancilliary Benefits of Reduced Air Pollution in the US from Moderate greenhouse gas Mitigation policies in the Electricty Sector". Journal of Environmental Economics and Management V(45)3: 650-673.

Chang, Yong-Tae, Thomas A. Grigalunas, and Mathew Luo, 1999. "Comprehensive Framework for Assessing US East Coast Container Shipping”, Korean Observer.

Cropper, Maureen, 2000. "Has Economic Research Answered the Needs of Environmental Policy?" J. of Env. Econ. and Management 39(3): 328-350 (May).

Desvouges, William H., Michael C. Naughton, and George R. Parsons, 1992.

"Benefit-Transfer: Conceptual problems in Estimating Water Quality Benefits Using Existing Estimation”. Water Resources Research, Vol. 28 No. 3, (Mar.): 675 $-683$.

Federal Register, 2003. "Draft 2003 Report to Congress on the Costs and Benefits of Federal Regulations: Notice". Part VII. Office of Management and Budget, pp. 5492-5527 (Monday, February 3).

Freeman, A. Myrick III, 2003. Value of Environmental and Natural Resource Services: Theory and Methods. Washington, D.C.: Resources for the Future.

Grigalunas, Thomas, James J. Opaluch and Mathew Luo, 2001. "Estimating the Cost to Fisheries from Dredge Disposal: Case Study of Providence, Rhode Island", Ecological Economics.

Grigalunas, Thomas and Meifeng Luo, and YT Chang, 2001. Comprehensive Framework for Sustainable Container Port Development for the United States East Coast: Year One Final Report. URI-TC Project No. Grant 536106. 
Kingston, RI USA: URI Transportation Center.

Grigalunas, Thomas and Meifeng Luo, and BM Jung, 2002. Comprehensive

Framework for Sustainable Container port Development for the United States East Coast: Year Two Final Report. URI-TC Project No. Grant 536106. Kingston, RI USA: URI Transportation Center.

Grigalunas, Thomas, YT Chang, and M. Luo, 2002. "Container Port Investment Appraisal and Risk Analysis: An Illustrative Case Study", Transportation Record: J. of the Transportation Research Board. (No.1782): 64-72 (Sept.).

Grigalunas, Thomas J. Opaluch, Yong-Tae Chang, M. Luo, 2001. "Environmental Costs in Container Port Development," Transportation Research Record: J. of the Transportation Research Board No. 1756.

Grigalunas, Thomas, J. Opaluch, and M. Luo, 2003. "Economic Issues in Dredging Windows: Framework, Model and Examples". WEDA J. of Dredging Engineering.

Hall, June V., Victor Brajer, and Frederick W. Lurman, 2003. "Economic Valuation of Ozone-Related School Absences in the South Coast Air Basin of California". Contemporary Economic Policy 21(4): 407-417.

Hanley, Ned, Jason Shogren, and Ben White, 1997. Environmental Economics in Theory and Practice. New York: Oxford University Press.

Hanemann, Michael, 1991. "Willingness to Pay and Willingness to Accept: How Much Can They Differ?" Amer. Econ Review 81: 635-47.

Hausman, Jerry, 2003. Continent Valuation: A Critical Assessment. New York: North Holland Publ. Co.

Johnston, Robert, James Opaluch, Thomas Grigalunas, and Marisa Mazzotta, 2001. "Estimating Amenity Beneifts of Coastal Farmland. Growth and Change 32: 305-25.

Knecht, J. and and J.A. Sinden, 1984. "Willingness to Pay and Compensation Demanded: Experimental Evidence of an Unexpected Disparity in Measures of Value". Quarterly Journal of Economics, 507 - 521.

Luo, Meifeng, 2002. Container Transportation Service Demand Simulation Model for US Coastal Container Ports .Ph.D. Dissertation, Department of Environmental and Natural Resource Economics, University of Rhode Island.

Luo, Meifeng and Thomas Grigalunas, 2003. "A Spatial-Economic Model of Container Port and Related Multimodal Transportation Demand”, J. of Maritime Economics and Logistics. 5:158 - 178.

Mansfield, Carol, Geogre Van Houten, and Joel Huber, 2002. "Compensating for Public Harms". Land Economics. 3(78): 368-389.

Mazzotta, Marisa J. and James J. Opaluch, 1995. Decision Making When choices Are Complex": A Test of Heiner's Hypothesis". Land Economics Vol 71 No. 4 (Nov.).

Opaluch, James, Thomas Grigalunas, Marisa Mazzotta and Jerry Diamantides, 1999. Resource and Recreational Values for the Peconic Estuary System. Peacedale, RI: 
Economic Analysis Inc.

Ozbay, Kaan, Bekir Bartin, and J. Berechman, 2001. Estimation of the Full Marginal Cost of Highway Transportation in New Jersey". J. of Trans. and Statistics 4(1): 81-103

Ricklefs, John and William Ellis, 2001. "Port of New York and New Jersey Inland Satellite Ports Initiative”. Proceedings, $80^{\text {th }}$ Annual Meeting, Transportation Research Board, Jan. 7-11, Washington, D.C.

Rowe, Robert, et al., 1995. The New York State Externalities Case Study. Haggler

Bailly Consulting, Inc. Dobbs Ferry, Ocean Publ. New York.

Transportation Research Board, 2002. Environmental Research Needs in

Transportation. Conference Proceedings 28. Washington, D.C.: Transportation Research Board, National Academy of Sciences.

US, Environmental Protection Agency, 2002 (www.epa.gov)

US Environmental Protection Agency, 2002. "Application of Mobile 5b for No. Kingstown, RI”. Washington, D.C.: EPA Office of Air Resources.

\section{Appendix A. The Container Port and Related Intermodel Simulation Model}

\section{A.1. Introduction}

This section outlines the basic model and key assumptions used to apply the container port demand simulation model. For further details, including references, see Luo (2002) and Luo and Grigalunas (2003).

The model is designed to estimate container port demand by simulating the container transportation process through a multi-modal transportation system including ports, rail, highway, and international shipping. We distinguish between the purpose of the work reported on in this chapter-to estimate demand-and the estimation of the market equilibrium, which includes both demand and supply and is outside the scope of this work.

The model assumes shippers select a route that minimizes the general cost over the whole transportation process; 1999 is used as a base year for trade data, aggregate trade, and its composition; and at this point, we use readily available economic parameters. The rationale for selecting the simulation method and the important implication of these (and other) assumptions are explained in detail in Luo (2002) and in Grigalunas, Luo and Chang, (2002). In ongoing research we are relaxing some of these restrictive assumptions and improving upon the data used in this chapter.

Next, the economic reasoning and model formulation for calculating general transportation cost are explained. We also discuss the computational algorithm and the simplified software architecture of this model.

Container transportation demand is derived from the demand for international trade in containerized goods. Container routing in the model depends on the origin and destination of the cargo, and how shippers select the route along which to 
transport the cargo. Many routes could be used for transporting a container between one point in the US and a foreign country. Some routes may use more water transportation but less land transportation (truck and rail), so the transportation cost is low, but it may take a longer time to reach the destination. Other routes use less sea transportation route but longer land transportation, so that the transportation cost is higher, but less time is needed to reach the destination. For the transportation process that is more shipping intensive, the model assumes some savings in lower freight rates will be realized, but it takes longer time, resulting in a higher opportunity cost of capital, higher depreciation cost for some cargo, and higher refrigerated box ("reefer box") renting cost for cargoes that need to be frozen during the transportation process.

In short, trade offs exist between the transportation cost and the time cost in the route selection decision. In the model, the shipper selects the route which minimizes the total cost in the transportation process from the origin to the destination, where total cost includes the freight rate paid to the transportation facility provider according to usage, and the interest cost on the value of cargo, which varies with the time spent in travel, cargo value, and the interest rate.

In the model, each route is assumed to use only one coastal port. By selecting a least-cost route, the port that a container of typical cargo will go through is also determined in the model. The aggregation of all containers that go through that port gives the simulated container transportation demand for that port. Next, the basic model for the simulation of container transportation for US coastal container ports is described.

Assume there are $Q_{a m i}$ containers (in TEU) of cargo category $i(i \in[1, I])$ that are to be imported from world region $a$ (a continent) to one destination $m$ in US (exporting is a reverse process of importing). The ship cost is ( dollars per mile per TEU. There are $N$ coastal ports to choose from in the US, the distance of region a to the $n^{\text {th }}(\mathrm{n} \in[1$, $N]$ ) container port is $l_{a n}$, The port charge at $n^{t h}$ port is $p_{n}$ per container. The domestic transportation cost from the $n^{\text {th }}$ port to the destination $\mathrm{m}$ is the sum of the costs of each mode. Assume for mode $j$ ( $j \in\left[\right.$ truck, rail]) the unit cost is $\beta_{n m j}$ per container per mile, with inland transportation distance $l_{n m j}$. The sea transportation speed is $S_{s}$ miles per hour, domestic transportation speed is $S_{L j}$ miles per hour and the port dwelling time for $n^{\text {th }}$ port is $H_{n}$ days. Also assume the value of container is $V_{i}$, and the daily unit cost of capital is $\rho$.

Transportation cost is the sum of the fees paid to the transportation facility providers for the use of the facilities (truck, rail, port and container vessel). For some routes, railway may not be used, so rail cost may not appear.

\section{A.2. Mathematical Model}

For one container from an origin in a particular world region, $a$, to a particular place $m$ in the US, the transportation $\operatorname{cost}\left(C_{l}\right)$ using $n^{\text {th }}$ port is:

$$
C_{l}(n)=\alpha^{*} l_{a n}+P_{n}+\sum_{j} \beta_{n m j} * l_{n m j}
$$


- Time Cost

The time spend on sea leg is: $\frac{l_{a n}}{24 S_{s}}$ days, port $H_{n}$ days, and domestic $\sum_{j} \frac{l_{n m j}}{24 S_{l j}}$ days, thus total number of days spent in transit is $D_{n}=\frac{l_{a n}}{24 S_{s}}+H_{n}+\sum_{j} \frac{l_{n m j}}{24 S_{L j}}$.

For cargo $i$, the opportunity cost of time for the cargo value:

$$
C_{2}(n)=V_{i}\left[(1+\rho)^{\left.D_{n}-1\right]}\right.
$$

Other costs that can be expressed as a function of time, like cargo depreciation, refrigerated container rental, can also be included in this part.

- Total cost in the transportation process

The total cost in transit by using $n^{\text {th }}$ port is the sum of the costs in the above two part:

$$
T C_{i}(n)=\alpha^{*} l_{a n}+P_{n}+\sum_{j} \beta_{n m j} * l_{n m j}+V_{i}\left[(1+\rho)^{D_{n}}-1\right]
$$

Assuming the shipper selects least-cost route, the selected port is the one that minimizes $T C_{i}(n)$. i.e.,

$$
\min _{n}\left\{T C_{i}(n)\right\}
$$

Assume through the selection of the least cost route, $Q_{a m i}^{n}$ containers of cargo $i$ move from $a$ to $m$ will use port $n$, then the annual demand of port $n\left(Q(n)^{2 l}\right)$ is:

$$
Q(n)=\sum_{a} \sum_{m} \sum_{i} Q_{a m i}^{n}
$$

As can be seen from the above discussion and equations, changes in sources, speed of transportation facilities, availability and/or costs of different ports or multimodal facilities, and in markets will affect the demand for port services. The model can be used to examine changes in these (and other) factors.

\section{A.3. Shortest Path Algorithm}

The core of the simulation model is the shortest path algorithm, which has been widely applied in economic analysis transportation engineering (Bank,1998; Ertl, Gerhard, 1998, Beuthe, et al., 2001; Fowler 2001; HDR Engineering, Inc, 2001), operations research (Hillier and Lieberman, 1974), and computer network routing (Kurose and Ross, 2000). It is one of the dynamic programming approaches described

\footnotetext{
${ }^{21}$ As a conditional demand estimation, this research focuses on conditional demand and does not consider any constraints which may exists on $Q(n)$ for each existing port $n$. Of course, port throughput is constrained by natural or legal factors. These constraints need to be addressed in a port equilibrium analysis planned for subsequent research.
} 
by Bertsekas, (1995).

Shortest-path problems can be stated in many ways. Here, we adopt the common notation used in the dynamic programming method. Assume the multimodal transportation network consists of a set of nodes $V=\left\{v_{i} \mid i \in[1, n]\right\}$, then the shortest path from one node (assume node 1) to all other nodes can be formulated as a deterministic dynamic programming problem as follow (Kronsjo and Shumsheruddin, 1992; Bertsekas, 1995):

$$
\begin{aligned}
& d_{i}=0 \\
& d_{i}=\min _{k \bullet E_{i}}\left\{C_{k i}+d_{k}\right\} \text { for } i=1, \ldots, n
\end{aligned}
$$

where $\mathrm{n}$ is the number of nodes in the network; di is the total cost from the starting node to node $i ; E_{i}$ is a subset of nodes that has a direct connection to node $i, E_{i}=\left\{v_{i} \mid i \in\right.$ $[1, k]\} ; c_{k i}$ is the general cost from one of these nodes to node $i$.

In implementing the simulation model, we use one efficient version of the shortest path algorithm for the single source, multiple destination problems - the Dijkstra Algorithm. This has been classified as "Best First Search" algorithm (Bertsekas, 1995).

\section{A.4. Overview of the Simulation Software}

To apply the model, the simulation software used is developed using Java programming language. It is designed so that the users can interact with the simulation software and do simulation analysis using a Graphical User Interface (GUI). The GUI is designed using Java Swing technology. To facilitate the visualization of simulation data, this simulation software also included the design and implementation of a GIS data graphical representation using Java. 


\section{Appendix B: Air Pollution, Sources and Effects}

Summary of Air Pollution Sources and Potential Health, Environmental, and Property Damage Effects

\begin{tabular}{|c|c|c|c|c|}
\hline POLLUTNT & POLLUTIONSOURCES & HEALTH EFFECTS & $\begin{array}{l}\text { ENVIRONMENTAL } \\
\text { EFFECTS }\end{array}$ & $\begin{array}{l}\text { PROPERTY } \\
\text { DAMAGE }\end{array}$ \\
\hline Ozone & $\begin{array}{l}\text { Chemical reaction of VOCs and NO, } \\
\text { in the atmosphere }\end{array}$ & $\begin{array}{l}\text { Breathing problems, reduced lung } \\
\text { function, asthma, irritates eyes, } \\
\text { stuffy nose, reduced resistance to } \\
\text { colds and other infections, may } \\
\text { speed lung tissue aging. }\end{array}$ & $\begin{array}{l}\text { Ozone can damage } \\
\text { plants and trees. Smog } \\
\text { can cause reduced } \\
\text { visibility }\end{array}$ & $\begin{array}{l}\text { Damages rubber, } \\
\text { fabrics, etc. }\end{array}$ \\
\hline $\begin{array}{l}\text { Nitrogen } \\
\text { Dioxide }\end{array}$ & $\begin{array}{l}\text { Burning of gasoline, natural gas, } \\
\text { coal, oil etc. Cars are an important } \\
\text { source of } \mathrm{NO}_{2}\end{array}$ & $\begin{array}{l}\text { Lung damage, illnesses of breathing } \\
\text { passages and lungs (respiratory } \\
\text { system) }\end{array}$ & $\begin{array}{l}\mathrm{NO}_{2} \text { is an ingredient of } \\
\text { acid rain (acid aerosols), } \\
\text { which can damage trees } \\
\text { and lakes. Acid aerosols } \\
\text { can reduce visibility }\end{array}$ & $\begin{array}{l}\text { Acid aerosols can } \\
\text { eat away stone used } \\
\text { on buildings, } \\
\text { statues, monuments, } \\
\text { etc. }\end{array}$ \\
\hline $\begin{array}{l}\text { Carbon } \\
\text { Monoxide }\end{array}$ & $\begin{array}{l}\text { Burning of gasoline, natural gas, } \\
\text { coal, oil etc. }\end{array}$ & $\begin{array}{l}\text { Reduces ability of blood to bring } \\
\text { oxygen to body cells and tissues; } \\
\text { cells and tissues need oxygen to } \\
\text { work. Carbon monoxide may be } \\
\text { particularly hazardous to people who } \\
\text { have heart or circulatory (blood } \\
\text { vessel) problems and people who } \\
\text { have damaged lungs or breathing } \\
\text { passages }\end{array}$ & & \\
\hline $\begin{array}{l}\text { Particulate } \\
\text { Matter }\end{array}$ & $\begin{array}{l}\text { Burning of wood, diesel and other } \\
\text { fuels; industrial plants; agriculture } \\
\text { (plowing, burning off fields); } \\
\text { unpaved roads }\end{array}$ & $\begin{array}{l}\text { Nose and throat irritation, lung } \\
\text { damage, bronchitis, early death }\end{array}$ & $\begin{array}{l}\text { Particulates are the } \\
\text { main source of haze that } \\
\text { reduces visibility }\end{array}$ & $\begin{array}{l}\text { Ashes, soot, smokes } \\
\text { and dusts can dirty } \\
\text { and discolor } \\
\text { structures and other } \\
\text { property, such as } \\
\text { clothes and furniture }\end{array}$ \\
\hline $\begin{array}{l}\text { Sulfur } \\
\text { Dioxide }\end{array}$ & $\begin{array}{l}\text { Burning of coal and oil, especially } \\
\text { high-sulfur coal from the Eastern } \\
\text { United States; industrial processes } \\
\text { (paper, metals) }\end{array}$ & $\begin{array}{l}\text { Breathing problems, may cause } \\
\text { permanent damage to lungs }\end{array}$ & $\begin{array}{l}\mathrm{SO}_{2} \text { is an ingredient in } \\
\text { acid rain (acid aerosols), } \\
\text { which can damage trees } \\
\text { and lakes. Acid aerosols } \\
\text { can also reduce } \\
\text { visibility }\end{array}$ & $\begin{array}{l}\text { Acid aerosols can } \\
\text { eat away stone used } \\
\text { in buildings, statues, } \\
\text { monuments, etc. }\end{array}$ \\
\hline Lead & $\begin{array}{l}\text { Leaded gasoline (being phased out), } \\
\text { paint (houses, cars), smelters (metal } \\
\text { refineries); manufacture of lead } \\
\text { storage batteries }\end{array}$ & $\begin{array}{l}\text { Brain and other nervous system } \\
\text { damage; children are at special risk. } \\
\text { Some lead-containing chemicals } \\
\text { cause cancer in animals. Lead causes } \\
\text { digestive and other health problems }\end{array}$ & Lead can harm wildlife & \\
\hline VOCs & $\begin{array}{l}\text { Burning of gasoline, oil, wood coal, } \\
\text { natural gas, etc.), and from use of } \\
\text { solvents, paints glues and other } \\
\text { products at work or at home. Cars } \\
\text { are an important source of VOCs. } \\
\text { VOCs include chemicals such as } \\
\text { benzene, toluene, methylene } \\
\text { chloride and methyl chloroform }\end{array}$ & $\begin{array}{l}\text { In addition to ozone (smog) effects, } \\
\text { many VOCs can cause serious } \\
\text { health problems such as cancer and } \\
\text { other effects }\end{array}$ & $\begin{array}{l}\text { In addition to ozone } \\
\text { (smog) effects, some } \\
\text { VOCs such as } \\
\text { formaldehyde and } \\
\text { ethylene may harm } \\
\text { plants }\end{array}$ & \\
\hline
\end{tabular}

Source : US Environmental Protection Agency, 2002 